Mónica Amaral Ferreira

Beatriz Zapico Blanco (coords.)

\title{
GUIÃO EDUCATIVO
}

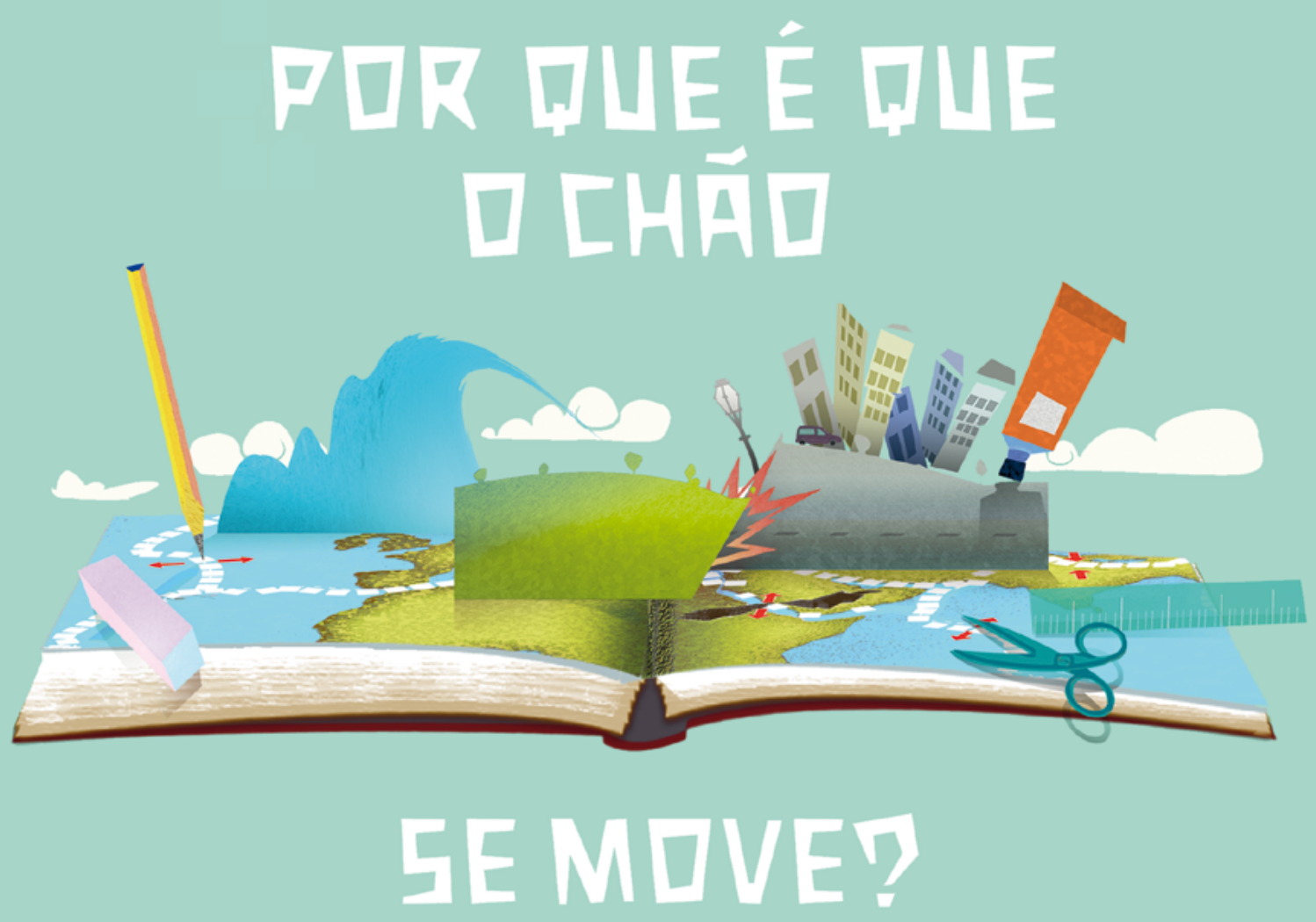


POR QUE É QUE 0 CHÃO SE MOVE? 


\author{
Mónica Amaral Ferreira \\ Beatriz Zapico Blanco (coords.)
}

\title{
POR QUE É QUE 0 CHÃO SE MOVE?
}

\author{
Projeto PERSISTAH \\ (Projetos de Escolas Resilientes aos SISmos \\ no Território do Algarve e de Huelva)
}

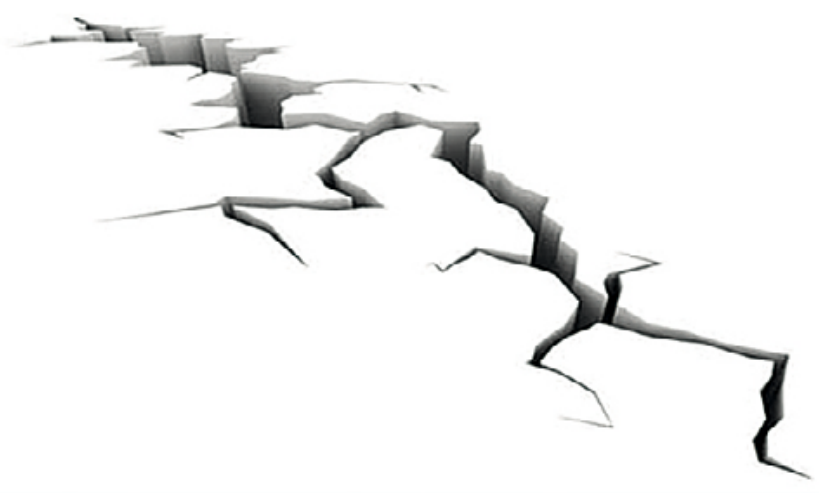

Mónica Amaral Ferreira

Carlos Sousa Oliveira, João Estêvão, Antonio Morales Esteban, Beatriz Zapico Blanco, Emilio Romero Sánchez, Jaime de Miguel Rodríguez, María Victoria Requena García de la Cruz y Luís Sá

Sevilla 2020 
Coleção Ediciones especiales

Ferreira, M.A.; Zapico Blanco, B.; Oliveira, C.S.; Estêvão, J.; Morales-Esteban, A.M.; Romero, E.; Requena, M.V.; de Miguel, J.; Sá, L. Por que é que o chão se move?, Ferreira, M.A.; Zapico Blanco, B. (coords.), Sevilla, Editorial Universidad de Sevilla, 2020.

\section{Comité editoriat}

José Beltrán Fortes

(Diretor da Editoria Universidade de Sevilha)

Araceli López Serena

(Subdiretora)

Concepción Barrero Rodríguez

Rafael Fernández Chacón

María Gracia García Martín

Ana Ilundáin Larrañeta

María del Pópulo Pablo-Romero Gil-Delgado

Manuel Padilla Cruz

Marta Palenque Sánchez

María Eugenia Petit-Breuilh Sepúlveda

José-Leonardo Ruiz Sánchez

Antonio Tejedor Cabrera

Todos os direitos reservados. Nem todo nem parte deste livro pode ser reproduzido ou transmitido por qualquer procedimento eletrónico ou mecânico, incluindo fotocópia, gravação magnética ou qualquer sistema de armazenamento e recuperação de informações, sem a permissão por escrito da Editoria Universidade de Sevilha.

Este trabalho foi desenvolvido no âmbito do projeto PERSISTAH, Projectos de Escolas Resilientes aos SIsmos no Território do Algarve e de Huelva (0313_PERSISTAH_5_P), desenvolvido em conjunto pelas universidades do Algarve e Sevilha e financiado pela Comissão Europeia através do programa EP - INTERREGVA Espanha Portugal (POCTEP).

\section{(d) Interreg España - Portugal PERSISTAH PROJECT

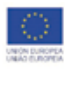

Ilustrações e design da capa: Hugo O’Neill

Edição digital da edição impressa 2020

(C) Editorial Universidad de Sevilla 2020

c/ Porvenir, 27 - 41013 Sevilla

Tlf. 954487 447; 954487451 - Fax 954487443

Correo electrónico: eus4@us.es

Web: <https://editorial.us.es>

(C) Mónica Amaral Ferreira y Beatriz Zapico Blanco (coords.) 2020

(C) Mónica Amaral Ferreira (Instituto Superior Técnico/Universidade do Algarve), Carlos Sousa Oliveira (Instituto Superior Técnico), João Estêvão (Universidade do Algarve), Antonio Morales Esteban (Universidad de Sevilla), Beatriz Zapico Blanco (Universidad de Sevilla), Emilio Romero Sánchez (Universidad de Sevilla), Jaime de Miguel Rodríguez (Universidad de Sevilla), María Victoria Requena García de la Cruz (Universidad de Sevilla) y Luís Sá (Autoridade Nacional de Emergência e Proteção Civil) 2020

ISBN-e: 978-84-472-3046-4

DOI: http://dx.doi.org/10.12795/9788447230464

Maquetagem e edição digital: Dosgraphic, S.L. (dosgraphic@dosgraphic.es) 
Consultora da área educativa e Revisão:

Patrícia Gramaxo (Doutora em Ciências da Educação, Professora do $1^{\circ}$ Ciclo do Ensino Básico)

\section{Agradecimentos:}

Dora Castelo (Museu de São Roque, Santa Casa da Misericórdia de Lisboa)

Luís Nobre (Museu de São Roque, Santa Casa da Misericórdia de Lisboa)

Carla Almeida (Serviço Municipal de Proteção Civil de Portimão, Professora do

$1^{\circ}$ Ciclo do Ensino Básico)

Rui Carrilho Gomes (Instituto Superior Técnico) 


\section{Índice}

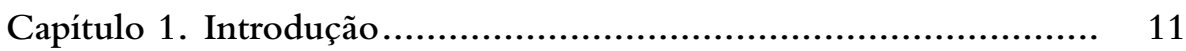

1.1. Educação para a redução do risco …………................................. 11

1.2. Sobre o guião educativo …................................................... 11

Capítulo 2. O que são os terramotos? ...................................... 15

Capítulo 3. Como medimos os terramotos?................................ 21

3.1. Escala de Richter............................................................... 22

3.2. Escala de Mercalli ........................................................................ 23

Capítulo 4. O que gera um tsunami? ..................................... 27

Capítulo 5. E nós por cá, estamos em risco? ................................. 29

5.1. Sismos e tsunamis mais destrutivos da península ibérica ................... 32

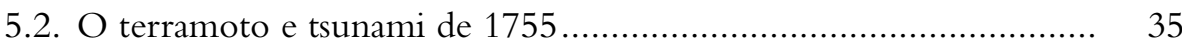

Capítulo 6. Por que é que a minha casa treme? ......................... 37

6.1. Como resistem os edifícios aos terramotos? ................................... 38

6.2. Importância dos elementos não-estruturais .................................... 40

6.3. Como reduzir o risco não-estrutural ............................................. 41

Capítulo 7. O que fazer em caso de sismo e tsunami? ................... 45

7.1. Se estiver na escola, o que devo fazer durante um sismo? ................. 45

7.2. Quais os locais mais perigosos dentro de um edifício durante um sismo? ............................................................... 45

7.3. Se estiver na rua, o que devo fazer durante um sismo? ..................... 45

7.4. O que devo fazer depois de um sismo? ........................................ 45

7.5. Em caso de tsunami, o que devo fazer?.......................................... 46

Capítulo 8. Atividades para alunos .............................................. 49

8.1. Puzzle placas tectónicas................................................................ 49

8.2. Não há duas sem três .................................................................. 52

8.3. Localiza os sismos no mundo .................................................... 54

8.4. Localiza os tsunamis no mundo.................................................... 56 


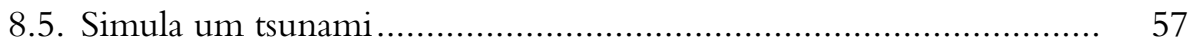

8.6. A casa Treme-Treme ............................................................... 58

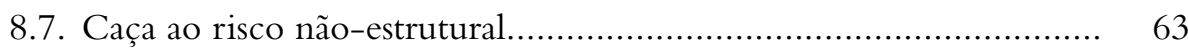

8.8. Maquete: Mover, proteger e fixar ............................................... 65

8.9. Descobre as diferenças: reduz o risco à tua volta ............................... 67

8.10. Jogo de computador:Treme-Treme ............................................... 69

8.11. Quantos Queres:Treme-Treme …………….......................... $\quad 70$

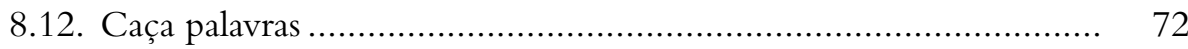

8.13. Jogo de tabuleiro KnowRISK ………………............................. 73

Capítulo 9. Cartaz | Segurança Sísmica nas Escolas....................... 75

Capítulo 10. Exemplo de protocolo experimental .......................... 77

Atividade experimental. Por que é que os sismos acontecem? ................. 77

Capítulo 11. Curiosidades ...................................................... 81

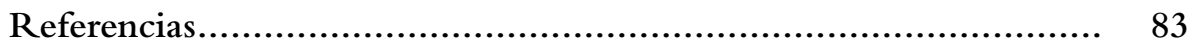

Índice de Figuras ......................................................... 85 


\section{Capítulo 1. Introdução}

\subsection{EDUCACÃO PARA A REDUÇ̃̃O DO RISCO}

O PERSISTAH (Projetos de Escolas Resilientes aos SIsmos no Território do Algarve $e$ de Huelva) é um projeto transfronteiriço Portugal-Espanha, financiado pelo programa INTERREG, que propõe desenvolver instrumentos de diagnóstico, avaliação, gestão e reabilitação dos equipamentos do ensino básico, e material de apoio aos docentes, enquadrando-se nos objectivos das Plataformas Nacionais para a Redução do Risco de Catástrofes (PNRRC) das Comissões Nacionais de Protecção Civil de Portugal e Espanha.

Um dos objetivos do projecto PERSISTAH é que a educação sirva para aumentar a resiliência das comunidades e a comunicação do risco seja estimulada, no sentido de formar indivíduos como cidadãos participativos e com uma cultura de risco.

Ao nível da prevenção e mitigação do risco sísmico, há que informar e educar a comunidade educativa, para a eventualidade dessa ocorrência, nomeadamente através da formação nas escolas, da identificação de potenciais riscos quer no interior quer no exterior dos edificios, da implementação das medidas de redução do risco estrutural e não-estrutural e da realização de exercícios de simulação.

\subsection{SOBRE 0 GUIÃO EDUCATIVO}

O guião educativo "Por que é que o chão se move?" foi concebido para apoiar a formação de professores, monitores e técnicos da área educativa do $1^{\circ}$ Ciclo do Ensino Básico (CEB), que queiram melhorar os seus conhecimentos e desenvolver atividades sobre o risco sísmico e de tsunami. Os conteúdos e informação contidos neste documento surgem de novas pesquisas agora realizadas, mas também na continuação de outros projectos em que a autora participou, designadamente o jogo sério "Treme-Treme" (<http://www.treme-treme.pt/>), 
iniciado com o projecto europeu UPStrat-MAFA (2013) e diversos materiais (jogos, vídeos e guia prático) para comunicação e educação do risco, no âmbito do projecto KnowRISK (2017).

A construção deste guião educativo teve por base as orientações contidas no Referencial da Educação para o Risco (RERisco, 2015). Um documento que está organizado por níveis de ensino, do qual constam os temas e subtemas a abordar para todos os riscos (naturais e tecnológicos) e os objetivos para os diferentes níveis de educação e ensino, tal como se descreve na Figura 1:

\section{$1^{\circ}$ Ciclo do Ensino Básico}

Subtema F: Sismo

- Conhecer as causas e susceptibilidades:

- Conhecer o conceito de sismo.

- Conhecer a escala de magnitude de Richter.

- Localizar áreas geográficas mais susceptíveis à existência de sismos.

- Distinguir os principais efeitos:

- Conhecer os efeitos primários dos sismos.

- Compreender as medidas de autoproteção:

- Identificar medidas apropriadas em situação de sismo.

- Ser capaz de cumprir/aplicar medidas de autoproteção.

SubTEMA G:TSUNAMI

- Conhecer as causas e susceptibilidades:

- Conhecer o conceito de tsunami.

- Localizar áreas geográficas mais susceptíveis à ocorrência de um tsunami.

- Distinguir os principais efeitos:

- Conhecer os diferentes efeitos diretos de um tsunami.

- Compreender as medidas de autoproteção:

- Conhecer sinais e avisos de eventual chegada de um tsunami.

- Ser capaz de cumprir/aplicar medidas de autoproteção.

Retirado do "Referencial da Educação para o Risco".

Figura 1. Organização do Referencial da Educação para o Risco (RERisco, 2015).

Para que os professores, monitores e técnicos da área educativa possam cumprir os objetivos expostos anteriormente é necessário terem ao seu dispor os recursos pedagógico e didácticos para formação inicial e contínua da comunidade escolar. Dada a inexistência desse material, o projeto PERSISTAH concebeu material pedagógico, que serve como uma ferramenta orientadora, e que explica os objetivos propostos no Referencial da Educação para o Risco, 
indo mais além ao incluir medidas de mitigação do risco. Esta ferramenta pode ser utilizada nos três tipos de aprendizagem (formal ${ }^{1}$, não formal ${ }^{2}$ e informal ${ }^{3}$ ), facilitando a interligação entre as aprendizagens das disciplinas e os domínios a serem abordados no currículo do $1^{\circ} \mathrm{CEB}$.

Pretende-se ensinar o fenómeno sísmico e a redução do risco a educadores e crianças de uma forma criativa, pedagógica e lúdica, integrando diversas atividades que promovem a participação individual e coletiva. Assim, desenvolve-se uma cultura de segurança nas crianças para que possam transpor para outros momentos do seu quotidiano, incentivando-as a resolver problemas e promovendo conexões com a vida real.

Este documento está dividido em duas partes e contém a existência de um conjunto de recursos e instrumentos ao serviço do ensino-aprendizagem, nomeadamente:

- Guião educativo para professores.

- Sugestões de atividades (que incluem jogos didáticos, puzzles, maquetas, mapas, entre outros) para que os professores, em conjunto com os seus alunos, explorem os temas de forma prática, criativa e baseada no questionamento e na experiência realizada pelos próprios alunos.

A diversidade de materiais pedagógicos expostos favorece múltiplas opções pedagógico-didáticas na ação dos professores, ao mesmo tempo que estimula e ajuda a captar a atenção de cada criança/aluno. O docente será responsável por selecionar e gerir os materiais considerando a sua adequação às características, necessidades e interesses das crianças, aos conteúdos curriculares, à natureza das aprendizagens e competências a promover (Correia, 1995; Graells, 2000).

Este guião educativo tem sido testado e implementado desde outubro de 2018, com alunos do pré-escolar (5 anos) e do ensino básico (6 aos 12 anos), nas atividades que decorrem nos períodos lectivos de 2018/2019 e 2019/2020 no Museu de São Roque em Lisboa:

1. "A terra treme! É um sismo!" e,

2. no workshop concebido para famílias que ocorre em parceria com o Instituto Superior Técnico e a Igreja e Museu de São Roque ("Se eu fosse... Engenheiro de Estruturas”);

1. Educação formal: desenvolve-se no seio do sistema de ensino -escolas e universidades- onde o aluno segue um programa pré-determinado, semelhante ao dos outros alunos que frequentam a mesma instituição (Chagas, 1993).

2. Educação não formal: processa-se fora do sistema de ensino e é veiculada pelos museus, meios de comunicação e outras instituições que organizam eventos de diversa ordem, tais como cursos livres, feiras e encontros.

3. Educação informal: ocorre ao longo da vida, de forma espontânea no dia-a-dia, através de conversas e vivências com familiares, amigos, colegas e interlocutores ocasionais. 
contribuindo para a aprendizagem científica não formal. Foi também utilizado para uma atividade experimental, na sala de aula, com 20 alunos do $1^{\circ}$ ano do $1^{\circ}$ CEB do Jardim-Escola João de Deus da Estrela, em Junho de 2019.

A colaboração de outros espaços que não a escola, como museus, universidades e centros de ciência são essenciais para a concretização e sucesso destes projetos.

Este guião educativo poderá interessar a outros públicos, nomeadamente, futuros professores do $1^{\circ} \mathrm{CEB}$, alunos de pós-graduação e ainda autores de recursos didáticos. 


\section{Capítulo 2. 0 que são os terramotos?}

A Terra é o planeta em que vivemos e tem a forma de uma bola, composta por muitas camadas, como se de um ovo cozido se tratasse. Para representar a estrutura interna da Terra podemos usar plasticina (Figura 2) ou mesmo um ovo cozido (Figura 3).
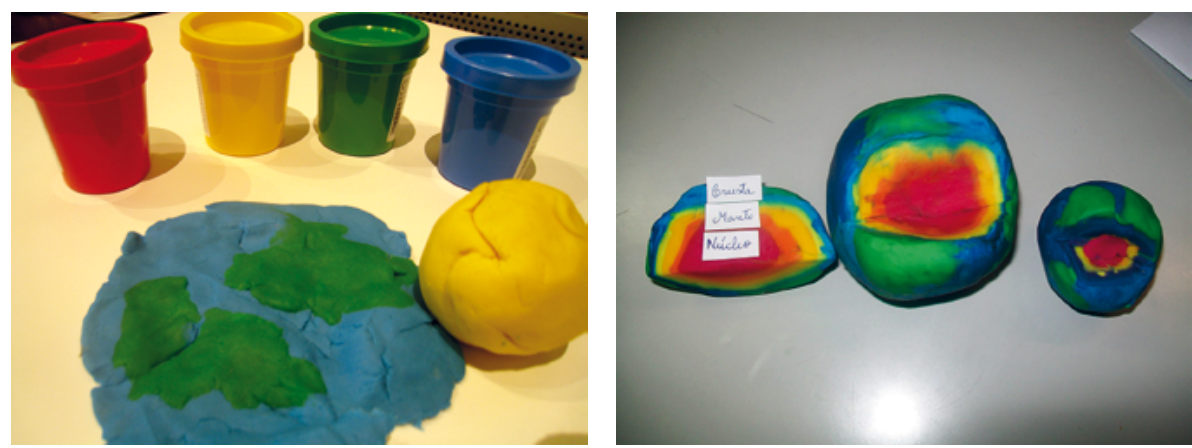

Figura 2. Representações do modelo da estrutura interna da Terra, usando plasticina de várias cores (Imagem da direita: <http://cienciasideiaxxi.blogspot.com>).
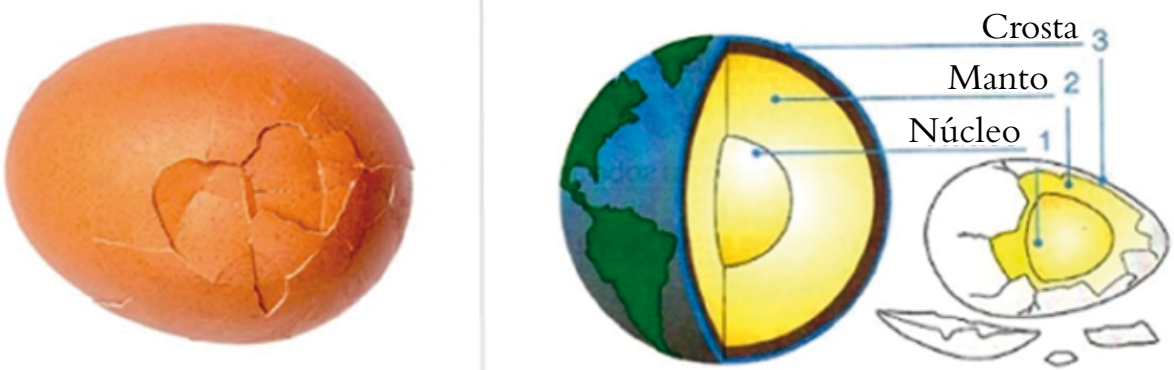

Figura 3. Estructura da Terra. 
Se cortarmos o ovo (a Terra) ao meio encontramos no interior o núcleo $(\mathrm{a}$ gema), pouco maior que a lua e extremamente quente. O núcleo é composto por metais, ferro e níquel.

A clara do ovo corresponde ao manto, uma camada com quase 3000 quilómetros de rochas muito densas, ricas em ferro e magnésio em que uma parte se encontra a elevadas temperaturas -o magma.

Por cima temos a crosta (onde nós vivemos), que forma os continentes e o fundo do mar -é feita de várias peças (lembrando a casca do ovo partido) enormes que se encaixam como se fossem um puzzle, e se chamam placas tectónicas (ou litosféricas).

O calor provoca o movimento dentro do manto e por isso as placas movem-se. Quando elas colidem umas contra as outras causam os terramotos (sismos ou tremores de terra).

Há cerca de 20 placas ao longo da superfície da Terra que se movem continuamente e lentamente umas sobre as outras. Quando as placas se aproximam ou afastam há compressão e ocorre um terramoto (exemplo das mãos/nós dos dedos, Figura 4).

Imagine as suas mãos como sendo "placas tectónicas" e os nós dos dedos a "fronteira de placas". Aproxime as mãos uma da outra para que os nós dos dedos fiquem juntos. Quanto mais empurrar os nós dos dedos, uns contra os outros, mais dificil é de a mão deslizar, começando a sentir-se a força nos nós dos dedos. Se continuar a pressionar por algum tempo, chegará o momento em que uma mão desliza sobre a outra (Figura 4 à direita). Quando isso acontece na Terra, é o equivalente ao movimento das placas, que libertam a energia acumulada, resultando num terramoto.
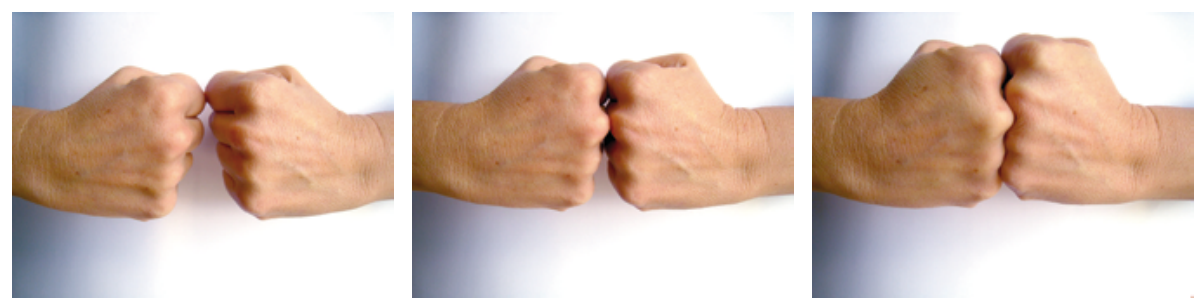

Figura 4. Representações de como as placas tectónicas colidem (Mónica Amaral Ferreira/Hugo O’Neill).

Também se pode utilizar um lápis para mostrar o fenómeno. Segure um lápis horizontalmente. Se aplicar uma força de ambas as extremidades do lápis, empurrando para baixo, vemos o lápis formar uma curva. Se continuarmos a fazer força, o lápis parte ao meio, libertando a tensão que colocámos nele. A crosta terrestre age da mesma maneira. Quando a rotura ocorre, a tensão é 
libertada como energia que se move através da Terra sob a forma de ondas, que nós sentimos e chamamos de terramoto (Figura 5).

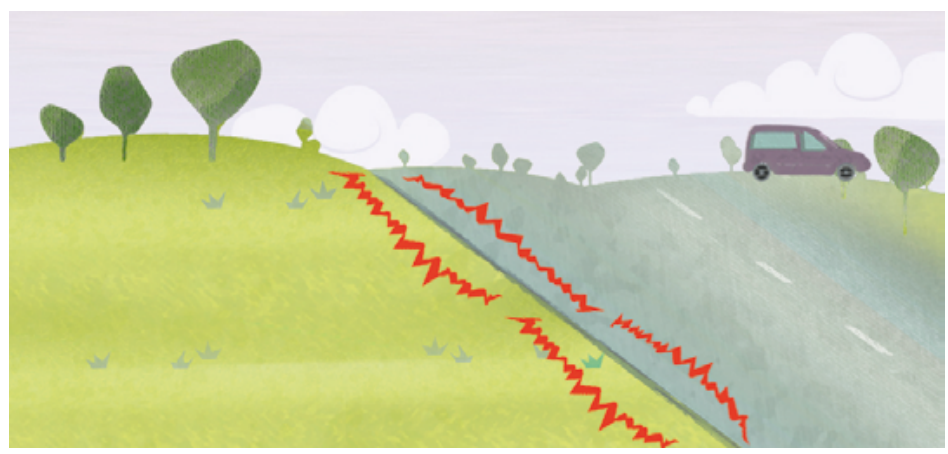

Colisão das placas.

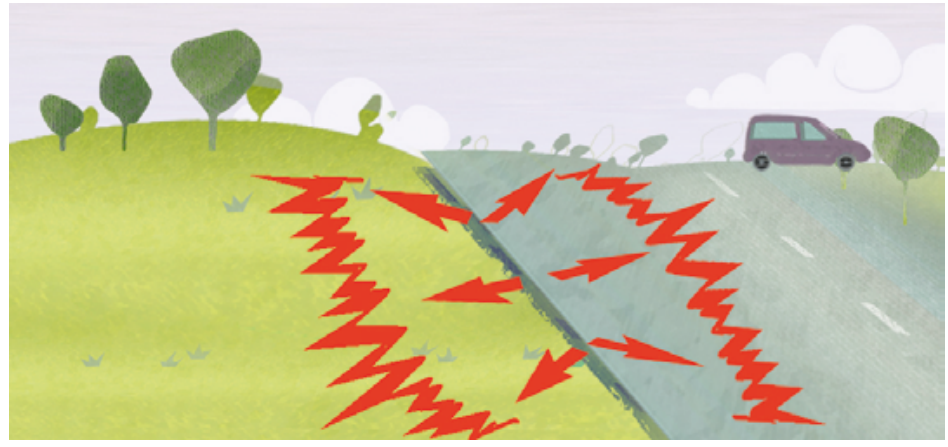

Quando a tensão é demasiado forte, ocorre a ruptura e é libertada toda a energia.

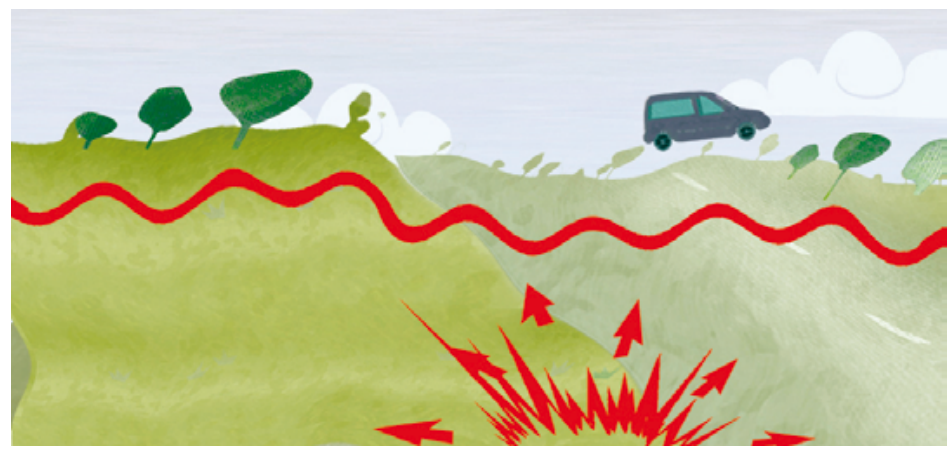

A vibração propaga-se pelo solo em todos as direções. É um terramoto.

Figura 5. Explicação “a terra treme” (Hugo O’Neill).

As fronteiras de placas são zonas muito ativas em termos de sismos e vulcões. Consoante o movimento das placas, as fronteiras (ou limites) entre elas podem ser: divergentes, convergentes ou transformantes, conforme ilustrado na Figura 6. 

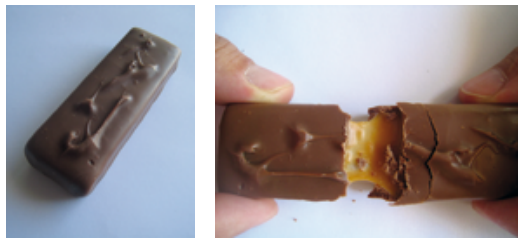

Divergente

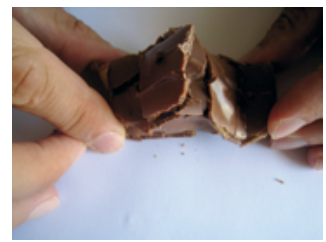

Convergente

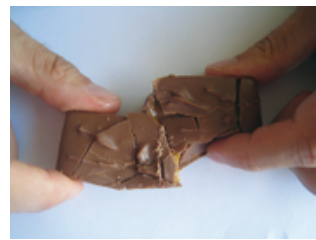

Transformante

Figura 6. Snack de chocolate representando os movimentos e fronteiras de placas (Mónica Amaral Ferreira/Hugo O’Neill).

- Fronteira Divergente: quando duas placas se separam e formam os riftes oceânicos. Os riftes são zonas de fratura onde ocorre ascensão do magma que, ao solidificar, formará o fundo oceânico (crosta oceânica, Figura 7). O exemplo mais conhecido de um limite divergente de placas é a dorsal médio-atlântica (uma cordilheira submarina que se estende sob o Oceano Atlântico, e o Oceano Ártico). Em alguns pontos do oceano é possível observar elevações da dorsal médio-atlântica que formam ilhas. Entre os locais destas elevações encontram-se a Islândia, as Bermudas e os Açores, onde está localizada a parte mais alta da dorsal, a Ponta do Pico -na ilha do Pico, com 2351 metros de altitude.

- Fronteira Convergente: quando duas placas colidem e causam subducção (Figura 7), ou seja, uma placa (crosta oceânica) mergulha sob a outra (crosta continental ou oceânica), formando fossas oceânicas e cadeias montanhosas (por exemplo a cordilheira dos Andes na América do Sul); terramotos e vulcões são comuns em torno de limites convergentes. A grande maioria dos tsunamis forma-se em consequência de sismos gerados em zonas de subducção.

- Fronteira Transformante: duas placas deslizam uma paralelamente à outra, em direções opostas.

Os terramotos podem ocorrer em terra ou no mar. Se houver um sismo forte (magnitude maior que 8) e estivermos junto à costa há risco de tsunami ou maremoto, que são ondas gigantes que podem ter a altura de um prédio e atingir a velocidade de um avião! (Ver Capítulo “O que gera um tsunami?”). Em Portugal podem ocorrer os dois tipos de terramotos: em terra e no mar, pelo que no nosso país também existe o risco de acontecer um tsunami. 


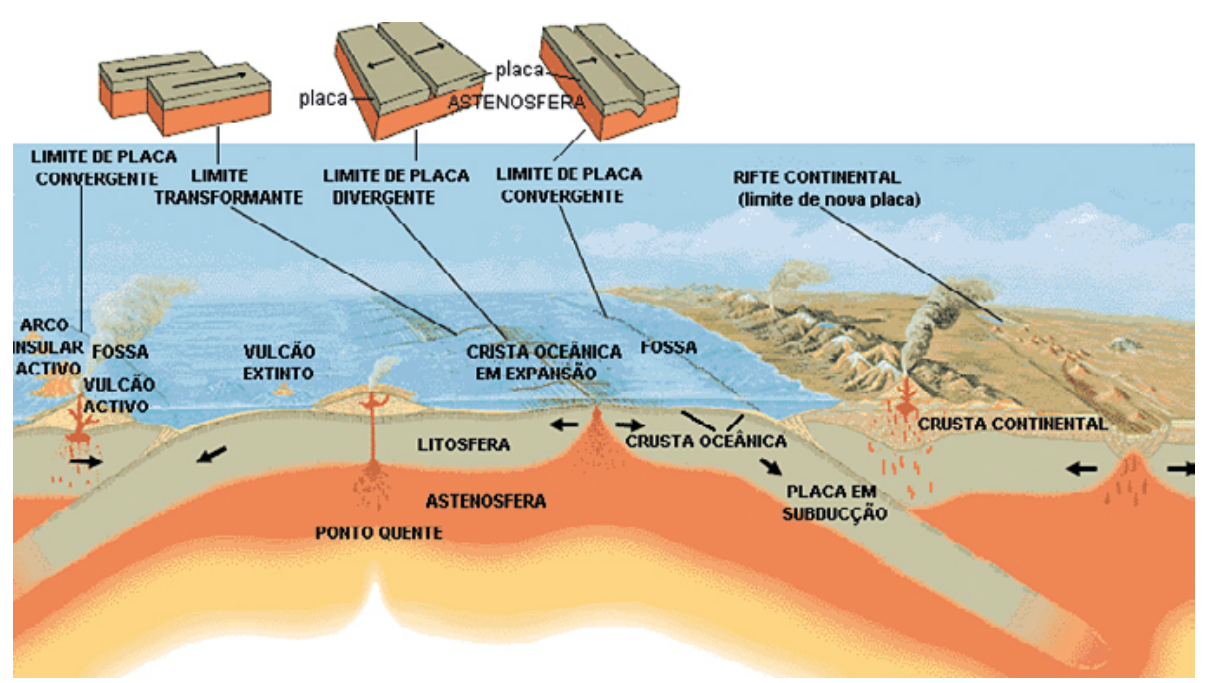

Figura 7. Exemplo de rifte, subducção, fossa, crosta oceânica e continental (fonte: $<$ http://www.lneg.pt/CienciaParaTodos/edicoes_online/diversos/guiao_tectonica_ placas/texto $>$ ).

No final deste capítulo os professores podem realizar as seguintes atividades:

\begin{tabular}{|l|l|}
\hline \multicolumn{2}{|c|}{ Sugestão de atividades para os alunos } \\
\hline Experiência do ovo cozido & Figura 2 \\
\hline Modelo do planeta Terra em plasticina & Figura 2 \\
\hline Snacks de chocolate que representam a crosta terrestre & Figura 4 \\
\hline Puzzle Placas Tectónicas & Página 49 \\
\hline
\end{tabular}




\section{INDICE}




\section{Capítulo 3. Como medimos os terramotos?}

Por ano acontecem mais de um milhão de terramotos na Terra, a maior parte de muito baixa magnitude, tão baixa que nem os sentimos. Em Portugal, são sentidos cerca de 25 terramotos por ano.

Os sismos ou terramotos podem ser fraquinhos, mas também muito fortes. Como conseguimos medir os sismos? O instrumento que regista as ondas sísmicas de energia que se movem através do solo, chama-se sismógrafo. Os movimentos são registados nos sismógrafos, que geram traçados gráficos denominados de sismogramas. A partir dos sismogramas os sismólogos conseguem obter informações, como a localização do hipocentro e a magnitude do sismo.

O hipocentro ou foco do terramoto, é o ponto no interior da terra (litosfera), onde se inicia o movimento sísmico, i.e., onde se dá a rotura. $\mathrm{O}$ epicentro é a projecção do hipocentro sobre a superfície terrestre, que é o lugar onde o sismo se sente com maior intensidade, onde ocorrem os maiores danos, tanto às pessoas como aos edifícios (Figura 8).

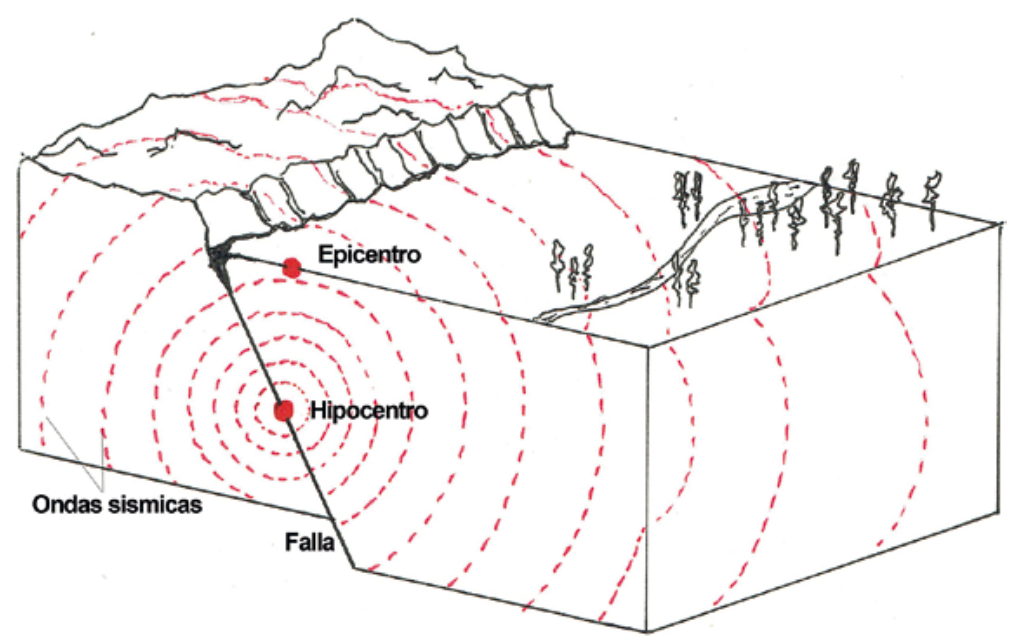

Figura 8. Hipocentro vs. Epicentro (Emilio Romero Sánchez). 


\subsection{ESCALA DE RICHTER}

Existem duas escalas que a sismologia utiliza para medir um sismo: a magnitude de "Richter" e a escala de "Mercalli".

A escala de Richter (que foi criada em 1935 pelos cientistas Charles Francis Richter) calcula a magnitude (energia libertada) de um terramoto. A escala de Richter não é uma escala linear, mas logarítmica, ou seja, multiplica-se por 10. Cada número é 10 vezes maior que o anterior. Então, para se ter uma ideia, a magnitude 5 é 10000 vezes maior que a magnitude 1 (Figura 9).

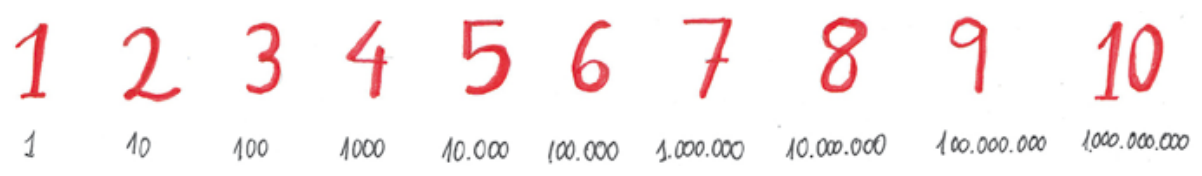

Figura 9. Richter e a escala logarítmica (Emilio Romero Sánchez).

O solo mover-se dez vezes mais significa que a quantidade de energia libertada é cerca de 32 vezes maior em comparação com o ponto anterior na escala. Ou seja, a magnitude 5 é cerca de 32 vezes maior que a magnitude 4, que é 32 vezes maior que a 3 e assim por diante (Figura 10).

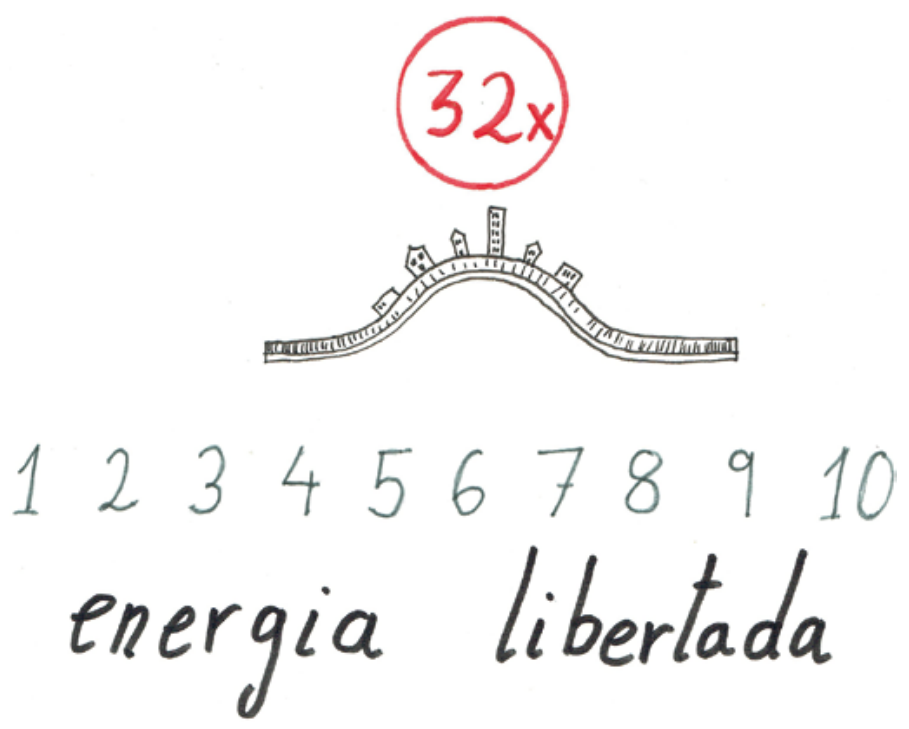

Figura 10. Energia libertada (Emilio Romero Sánchez). 
Só para termos uma ideia, a bomba de Hiroshima é equivalente a um sismo de magnitude 6 , enquanto o meteorito que exterminou os dinossauros, se calcula, que seria equivalente a um terramoto de magnitude 13 .

O maior terramoto já registrado foi de magnitude 9,5 e ocorreu em 1960 no Chile. Não há limite teórico para a magnitude de um terramoto, embora seja estimado que um terramoto de magnitude 15 destruiria o planeta, dividiria a Terra em duas.

A partir da magnitude 5, os edificios mais vulneráveis podem sofrer danos ligeiros a moderados; a partir da magnitude 7 , é muito provável que a maior parte sofra danos severos ou colapso (Figura 11).

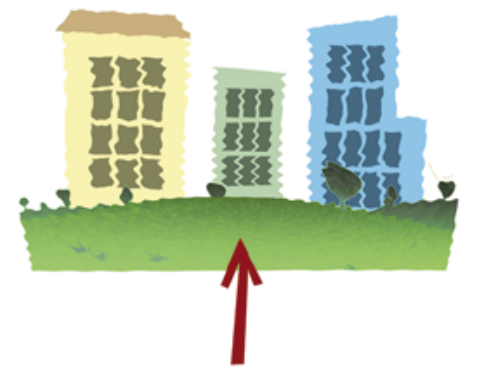

MAGNITUDE 5

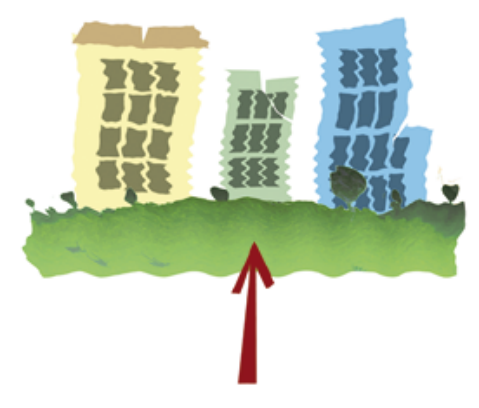

MAGNITUDE 7

Figura 11. Qual o efeito dos sismos nos edifícios? (Hugo O’Neill).

\subsection{ESCALA DE MERCALLI}

A Escala de Mercalli, criada em 1902 pelo sismólogo italiano Giuseppe Mercalli), é usada para medir a intensidade, ou seja, os efeitos de um sismo na população e nas construções. É uma escala de 12 graus (em numeração romana) em que cada grau representa a gravidade do terramoto -de impercetível até totalmente catastrófico (Figura 12). 

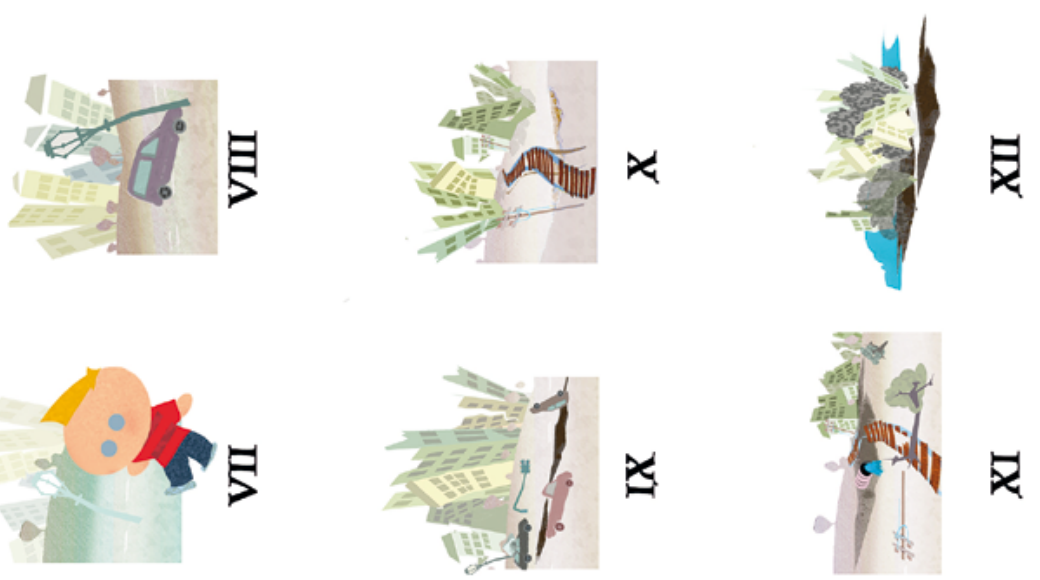

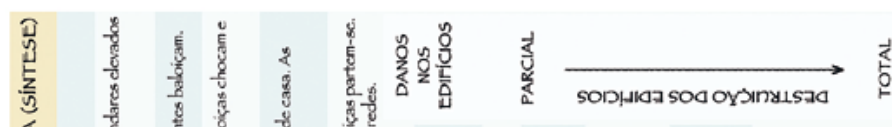
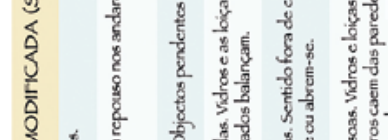

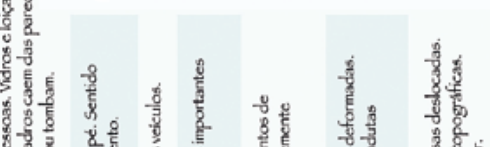

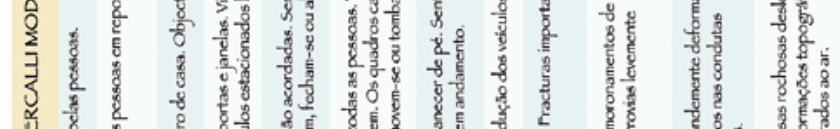

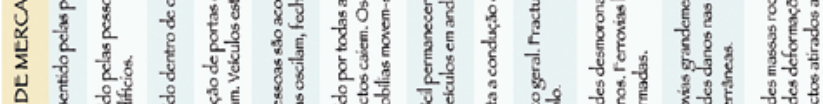

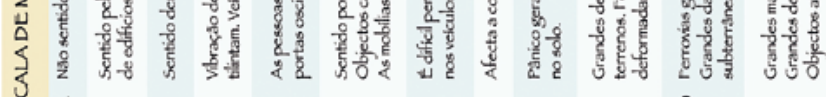

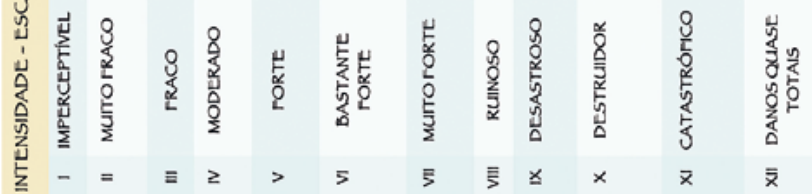

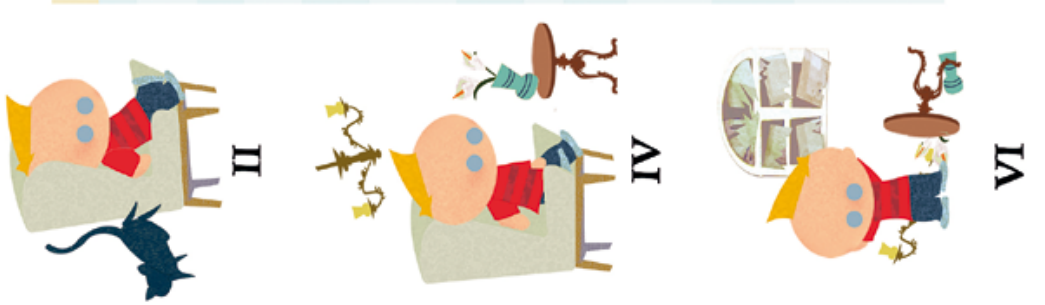

高

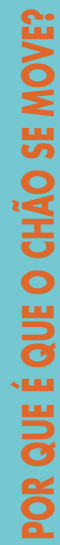


Seguem-se alguns exemplos dos sismos com maior magnitude que ocorreram em toda a história:

1. Valdivia, Chile, 22 de maio de 1960 (magnitude 9,5). Causou cerca de 1600 mortes no Chile, enquanto o tsunami que deu origem provocou mortes e danos tão distantes quanto o Havai, o Japão e as Filipinas. Dois dias depois do terramoto, o vulcão Puyehue, nas proximidades, entrou em erupção.

2. Alasca, 28 de março de 1964 (magnitude 9,2). O terramoto foi sentido principalmente no Alasca, bem como em alguns lugares no Canadá; este terramoto deu origem a um tsunami que causou danos tão distantes quanto o Havai.

3. Sumatra, Indonésia 26 de dezembro de 2004 (magnitude 9,3). O segundo maior sismo de que há registo instrumental, a seguir ao sismo do Chile em 1960. Sismo e tsunami causaram cerca de 335000 mortes e deixaram 150000 estudantes sem edificios escolares. Poucas horas depois o tsunami devastou a costa este da Tailândia, bem como o Sri Lanka, Índia e a costa oeste das Maldivas.

4. Tohoku, Japão 11 de março de 2011 (magnitude 9,0). O tsunami causou um desatre nuclear em Fukushima, levando à evacuação de milhares de pessoas por tempo indeterminado, num raio de 20 quilómetros. Cerca de 200 edifícios escolares foram destruídos e mais de 700 foram significativamente danificados pelo tsunami.

5. Kamchatka, Rússia, 4 de novembro de 1952 (magnitude 9,0). Este sismo gerou um tsunami que causou danos generalizados nas ilhas havaianas. O tsunami chegou até ao Alasca, Chile e Nova Zelândia.

6. Maule, Chile 27 de fevereiro de 2010 (magnitude 8,8). Este terramoto e subsequente tsunami mataram pelo menos 521 pessoas, e causaram 12000 feridos. Mais de 800 mil pessoas foram desalojadas. O sismo e tsunami destruíram ou danificaram mais de 3000 escolas no Chile, afetando 1,25 milhão de estudantes. Um pequeno tsunami atravessou o Pacífico causando danos a barcos tão distantes quanto San Diego, Califórnia.

7. Costa do Equador, 31 de janeiro de 1906 (magnitude 8,8). O terramoto causou um tsunami que fez entre 500 e 1500 vítimas no Equador e Colômbia. O tsunami atingiu a costa oeste dos EUA (São Francisco), e o Havaí e Japão. O tsunami levou cerca de 12 horas para atravessar o Pacífico até Hilo, no Havaí.

8. Portugal, 1 de Novembro de 1755 (magnitude 8,7-9,0). O megassismo com uma magnitude que se estima entre 8,7 e 9,0, foi sentido fortemente 
em Lisboa, Algarve, sul de Espanha e Marrocos. Embora sem causar danos, também foi sentido nos Açores (tendo causado danos no edificado de Ponta Delgada (São Miguel), Angra do Heroísmo e Praia da Vitória (Terceira), na Madeira e por quase toda a Europa. O número total de vítimas, é muito incerto com estimativas que variam entre 20000 e as 40000 pessoas. 


\section{Capítulo 4. 0 que gera um tsunami?}

E se um sismo ocorrer no mar? Quando um sismo ocorre no fundo do mar, este movimenta-se abruptamente e sobe; e uma grande quantidade de água desloca-se.É a primeira onda do tsunami. Um tsunami (que em japonês significa ondas de porto) ou maremoto, é uma onda muito veloz e baixa em mar aberto, mas ao aproximar-se da costa, onde o fundo se torna mais baixo, as ondas perdem velocidade mas a sua altura aumenta (podendo atingir $50 \mathrm{~m}$ de altura!) pois a energia permanece a mesma (Figura 13). Um tsunami pode causar grande destruição por onde quer que passe, tendo grande impacto social, económico e ambiental.

A Figura 13 explica como se gera um tsunami. Devido à fricção e devido ao facto de as placas se movimentarem lentamente durante a maior parte do tempo, a zona de subducção encontra-se normalmente bloqueada. Assim, a energia vai-se acumulando e as placas vão-se deformando lentamente. Quando a energia acumulada excede a força de fricção existente entre as duas placas dá-se o movimento repentino relativo entre elas ao longo do plano de subducção, libertando enorme quantidade de energia. A energia potencial é "transformada" em energia cinética (movimento). Quando isto acontece o fundo do mar pode movimentar-se bruscamente, movimento este que é transferido à coluna de água suprajacente, gerando o Tsunami.

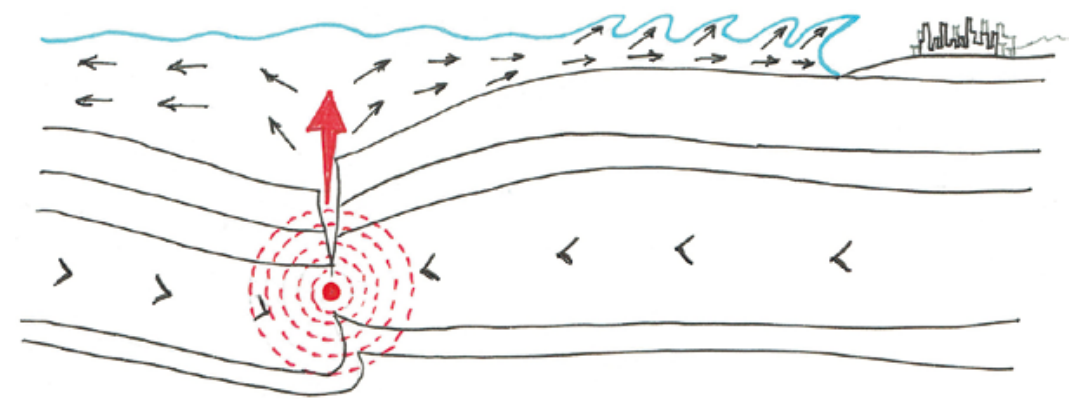

Figura 13. Geracão de um tsunami (Emilio Romero Sánchez). 
Os melhores sinais para sabermos identificar a ocorrência de um tsunami são dados pela natureza (Figura 14):

Se sentir um sismo forte, ou o chão a tremer, existe probabilidade de ocorrer um tsunami caso se encontre junto à costa.

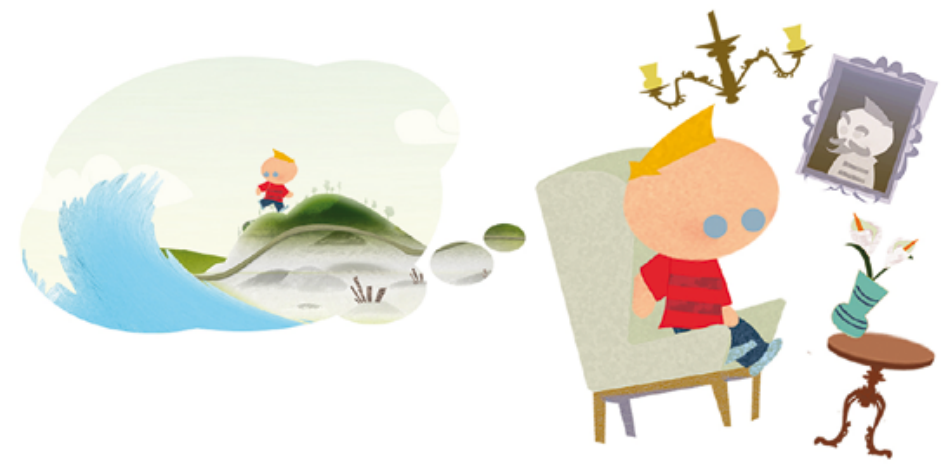

ANTES

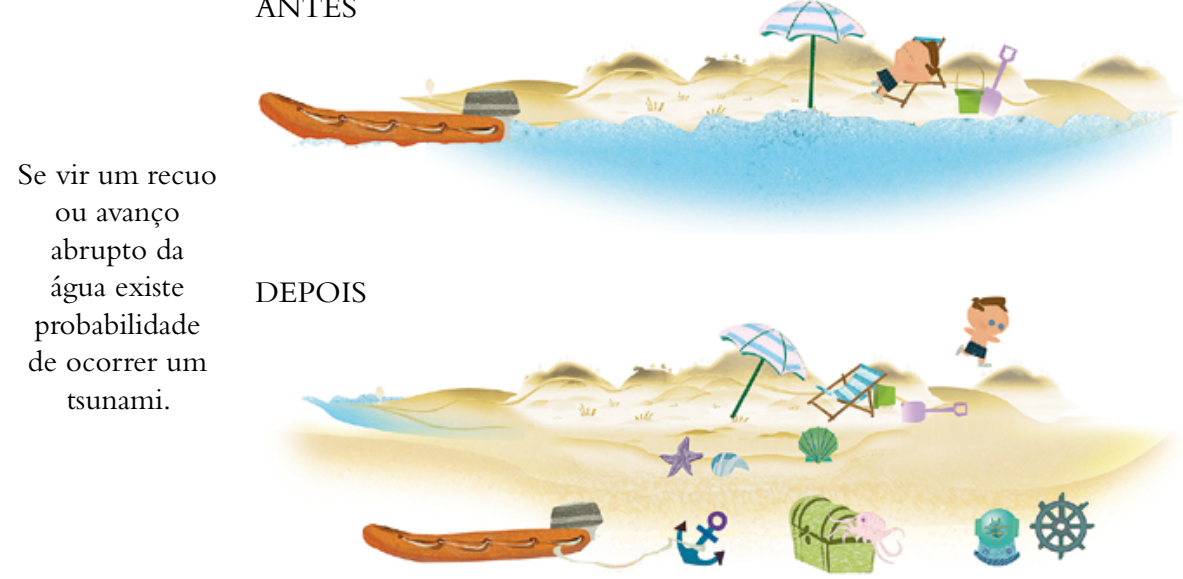

Figura 14. Sinais para sabermos identificar a ocorrência de um tsunami (Hugo O’Neill).

No final deste capítulo os professores podem realizar as seguintes atividades:

\begin{tabular}{|l|c|}
\hline \multicolumn{2}{|c|}{ Sugestão de atividades para os alunos } \\
\hline Não há duas sem três & Página 52 \\
\hline Localiza os sismos no mundo & Página 54 \\
\hline Localiza os tsunamis no mundo & Página 56 \\
\hline Caça palavras & Página 72 \\
\hline
\end{tabular}




\section{Capítulo 5. E nós por cá, estamos em risco?}

Existem três fatores que juntos determinam o risco sísmico:

1. O nível de perigosidade sísmica, ou seja, a exposição de um determinado local a fenómenos naturais relacionados com a ocorrência de sismos tais como, ação sísmica, liquefação, deslizamentos, tsunami. A perigosidade sísmica vem quantificada em termos probabilísticos que descrevem a probabilidade de um determinado nível de um parâmetro sísmico (intensidade, aceleração ou velocidade) ser excedido de um determinado nível.

2. O número de pessoas e construções expostas à perigosidade sísmica e

3. Quão vulneráveis (ou preparadas) estão as pessoas e as construções para resistir a essa perigosidade.

A Península Ibérica apresenta uma actividade sísmica moderada comparativamente a outras regiões do mundo, porém no sul da Península é onde se concentra a maior atividade sísmica, devido à convergência das placas EuroAsiática e Africana.

Portugal, devido ao seu enquadramento, tem sofrido as consequências de sismos de moderada a forte magnitude. Portugal localiza-se em regiões de média atividade sísmica (Figura 15); Portugal continental situa-se a norte da fronteira entre as placas Euro-Asiática e Africana (move-se cerca de $4 \mathrm{~mm} / \mathrm{ano}$ ). Os Açores situam-se na crista média do Atlântico, na proximidade da junção das placas Euro-Asiática, Africana e Americana.

O território português está dividido em quatro zonas sísmicas de acordo com a sua perigosidade (Figura 16): reduzida, baixa, moderada e elevada.

O Sul de Portugal Continental é a zona de maior risco sísmico, assim como o nosso litoral e as ilhas dos Açores, com exceção das ilhas das Flores e Corvo que, conjuntamente com as do arquipélago da Madeira, apresentam perigosidade reduzida. 


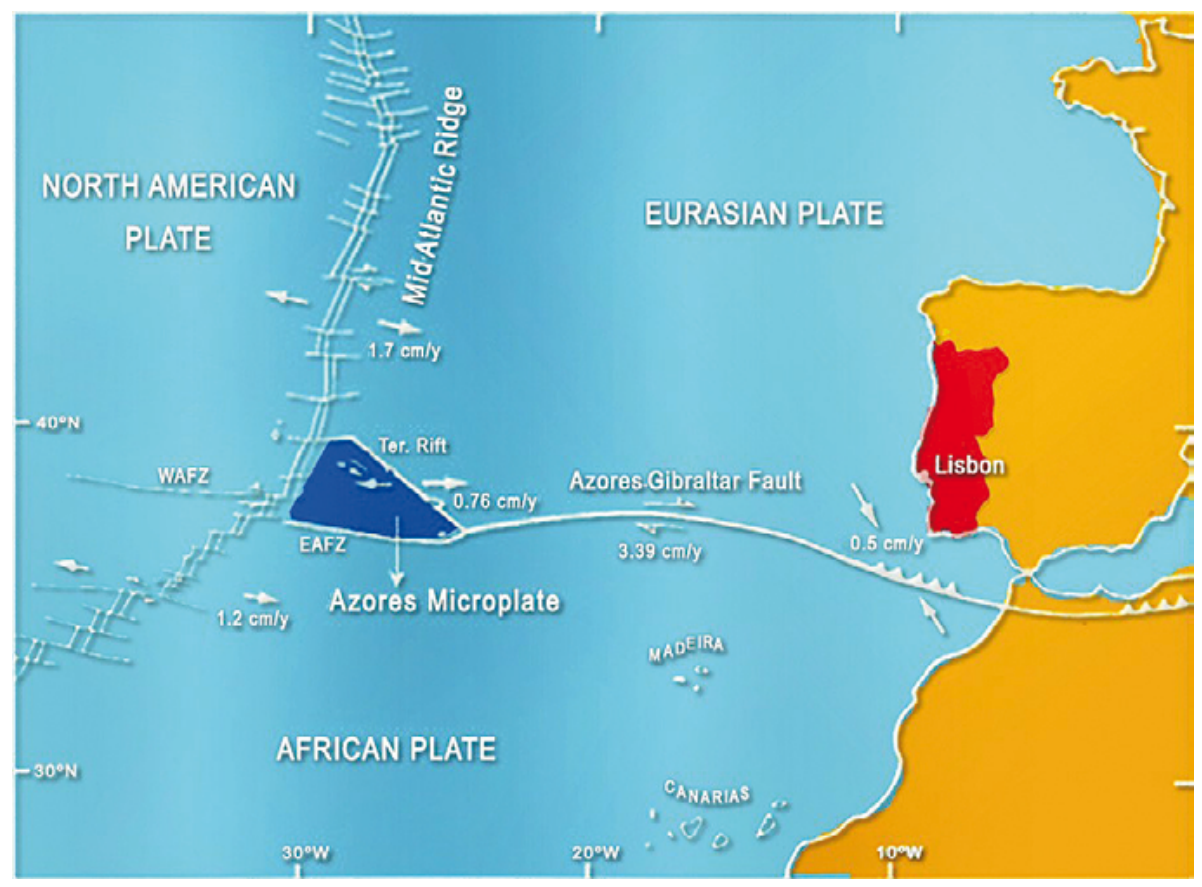

Figura 15. Modelo geodinâmico interpretativo para a colisão das Placas Euro-Asiática e Africana (fonte: adaptado de Nunes, 1999).

Em Portugal o risco de tsunami tal como o de sismos é real, sendo as regiões do Algarve, Costa Alentejana, Setúbal, Sesimbra, toda a zona ribeirinha de Almada, Alcochete, Lisboa e Costa do Estoril as zonas de maior risco. Entre os tsunamis mais catastróficos que atingiram a região portuguesa podem referir-se o de 24 de agosto de 1356, o de 26 de janeiro de 1531, que inundou Lisboa e o Vale do Tejo e o de 1 de novembro de 1755 (ondas que atingiram os $30 \mathrm{~m}$ de altura e estima-se que tenham morrido entre 40000 a 80000 pessoas). Todos estes tsunamis foram gerados por sismos com epicentro provável na zona de Gorringe, ou seja, no mar a sudoeste do Cabo de São Vicente.

Embora o risco de tsunami em Espanha não seja muito alto, a costa sudoeste da Península Ibérica é uma das áreas mais expostas à ação de tsunamis na Europa, devido a sistemas de falhas que marcam a fronteira entre as placas Euro-Asiática e Africana. 


\section{PORTUGAL CONTINENTAL}

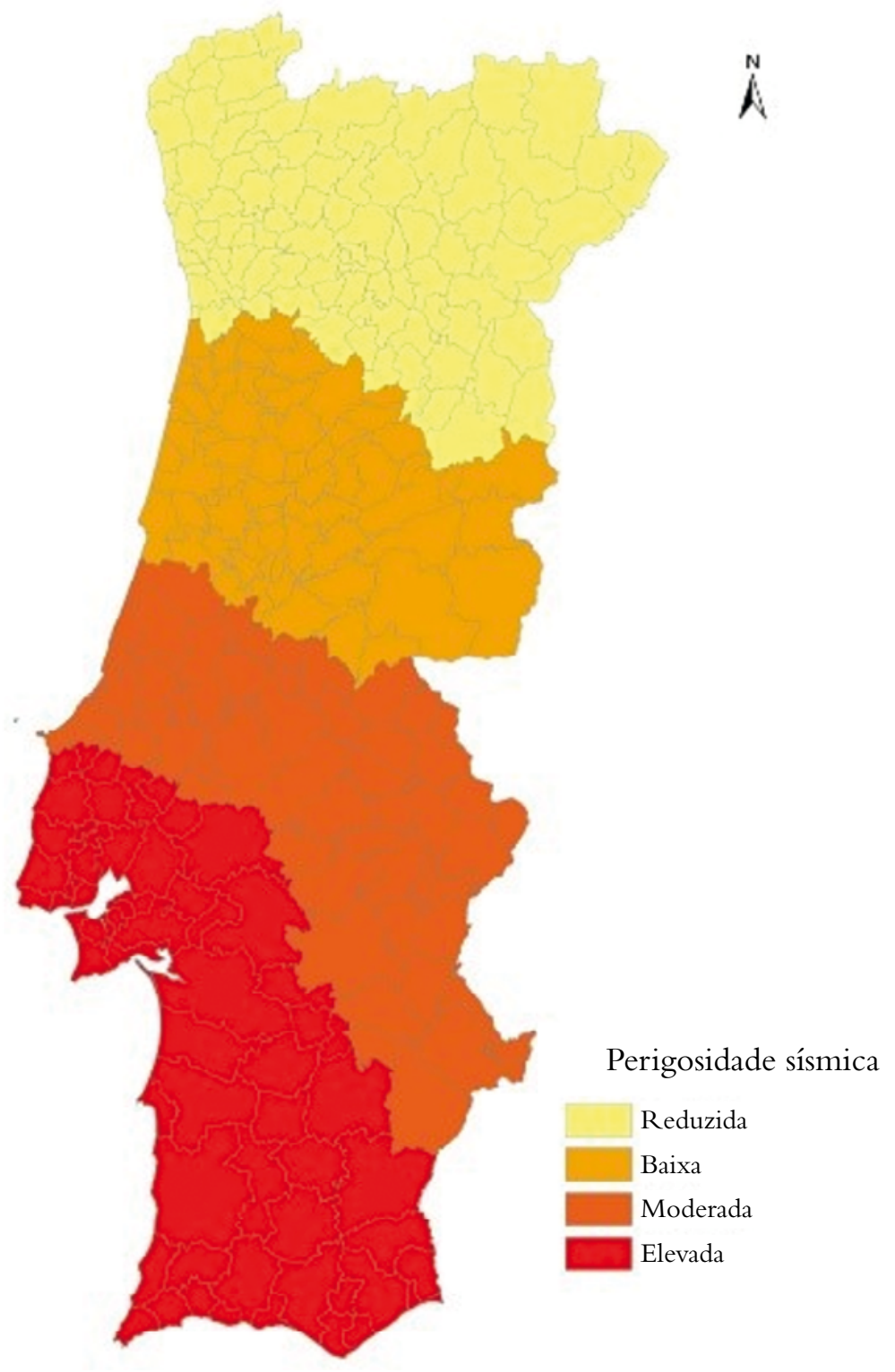

Figura 16. Perigosidade sísmica em Portugal Continental (Regulamento de segurança e acções para estruturas de edificios e pontes. 1983). 


\subsection{SISMOS E TSUNAMIS MAIS DESTRUTIVOS DA PENÍNSULA IBÉRICA}

De entre os acontecimentos que marcaram a história da sismologia na Península Ibérica podemos destacar:

- 22 de setembro de 1522. Teve uma magnitude estimada em 6,5, e epicentro na zona de Alhama de Almería (Espanha). Afetou gravemente a cidade de Almería e provocou danosnas áreas circundantes como Vera, Baza, Guadix ou Ugíjar, e na província de Granada. È considerado como o terramoto mais danoso da história de Espanha.

- 26 de janeiro de 1531. Causou danos no centro de Portugal continental, particularmente na região de Lisboa. Teve epicentro provável na região de Benavente (falha do Vale Inferior do Tejo). Pensa-se que a sua magnitude terá sido de 6,5. Foi sentida alguma agitação das águas do Tejo.

- 9 de outubro de 1680. Conhecido como o terramoto de Málaga de 1680, teve seu epicentro na Sierra de Aguas, e uma magnitude de 6,8. Causou sérios danos na cidade de Málaga e nas cidades vizinhos, tendo sido sentido em muitas cidades do centro e sul de Espanha.

- 27 de dezembro de 1722. Causou grandes estragos humanos e materiais desde o cabo de S.Vicente a Castro Marim, com incidência em Tavira, Faro e Loulé. Teve o seu epicentro no mar e gerou um tsunami local em Tavira.

- 1 de novembro de 1755. O maior dos sismos e tsunami de que há notícia histórica. Sentiu-se fortemente em Lisboa, Algarve, sul de Espanha e Marrocos. Embora sem causar danos, também foi sentido nos Açores (tendo causado danos no edificado de Ponta Delgada (São Miguel), Angra do Heroísmo e Praia da Vitória (Terceira), na Madeira e por quase toda a Europa. O megassismo de 1 de novembro de 1755, com uma magnitude que se estima entre 8,7 e 9,0, atingiu intensidades máximas de $\mathrm{X}$ no Algarve. $\mathrm{O}$ número total de vítimas, é muito incerto com estimativas que variam entre 20000 a 40000 pessoas. Só em Lisboa, pensa-se que dos 200000 habitantes da época, 20000 terão morrido. Das 20000 casas existentes, apenas 3000 podiam ser reocupadas a seguir ao sismo. Totalmente destruídos ou severamente danificados contam-se 32 igrejas, 60 capelas, 31 mosteiros, 15 conventos e 53 palácios. A resposta à catástrofe foi rápida; contudo, a reconstrução completa da cidade, prolongou-se no tempo por um período de 100 anos aproximadamente.

- 21 de fevereiro de 1964. Uma crise sísmica abalou a parte oeste da ilha de S. Jorge (Açores), com uma magnitude de 5,5, registando intensidades 
máximas de VIII/IX nos Rosais. Esta crise esteve associada a uma erupção submarina ao largo dos Rosais. No Pico atingiu intensidade máxima de VI na zona da Piedade e no Faial registaram-se intensidades máximas deV na Horta, Ribeirinha e Cedros.

- 13 de janeiro de 1804. Teve epicentro no Mar de Alborán, e registou uma magnitude de 6,3. Causando sérios problemas na cidade de Motril.

- 21 de março de 1829. Com uma magnitude de 6,6 e epicentro em Benejúzar, Rojales e Torrevieja, causou 389 mortos, 377 feridos, 2965 casas completamente destruídas, 2396 danificadas, e a destruição das pontes sobre o rio Segura em Almoradí, Benejúzar, Dolores e Guardamar. As povoações vizinhas de Almoradí, Algorfa, Rafal, Torrelamata, Daya Vieja, Guardamar, Dolores, Redován, San Fulgencio e San Miguel de Salinas foram também fortemente afetadas. A maior parte dos feridos foram localizados em Almoradí, e isto porque era uma povoação de ruas estreitas e edificios mais altos que caíram uns sobre os outros.

- 11 de novembro de 1858. Com origem próxima do vale submarino do Sado, associa-se um dos grandes sismos que afectaram Portugal. Atingiu uma intensidade X em Setúbal, provocando grande destruição em várias povoações.

- 23 de abril de 1909. O epicentro que se localizou na zona de Benavente (falha do Vale Inferior do Tejo), teve duração de cerca de 20 segundos. Com magnitude 6,0 teve intensidade máxima em Benavente de IX e em Lisboa de VII, sendo a parte oriental desta cidade a mais danificada, registando queda de chaminés, fendilhação de fachadas e muros.

- 28 de fevereiro de 1969. O sismo de magnitude 7,9 com localização epicentral na planície abissal da Ferradura, foi sentido em todo o país, atingindo uma intensidade máxima de VIII (Mercalli) no Barlavento Algarvio, com danos importantes em alguma construção de alvenaria antiga. Em Lisboa, centenas de chaminés sofreram danos, incluindo colapsos. A sul de Lisboa registaram-se danos ligeiros a moderados em diversas igrejas e capelas

- 23 de novembro de 1973. Os sismos desta crise, ocorreram nos dias 23 de novembro e 11 de dezembro com valores de magnitude de 5,8 e 5,6, respectivamente, atingindo as ilhas do Pico e Faial. O sismo causou 61 mortos e provocou graves danos, com muitas casas parcialmente destruídas, muros caídos e estradas obstruídas.

- 1 de janeiro de 1980. Este sismo que afectou as ilhas Terceira, S. Jorge e Graciosa (M 7,2), causou grandes estragos na cidade de Angra do Heroísmo, essencialmente em edifícios de um a dois pisos em alvenaria 
tradicional de pedra, danificando 15000 habitações (50\% do total existente) das quais 5000 atingiram o colapso. Um pequeno tsunami foi gerado por este sismo. O sismo causou 61 mortos muitos dos quais devido aos deslizamentos de encostas na ilha de S. Jorge. A reconstrução das zonas destruídas constituiu a operação de maior envergadura levada a cabo em Portugal nos últimos 100 anos.

- 9 de julho de 1998. Crise sísmica que teve início a 9 de julho de 1998, com epicentro a cerca de $15 \mathrm{~km}$ a NE da Horta e magnitude 5,9, registou perto de 10600 réplicas e durou cerca de 4 meses. O sismo causou 8 mortos, uma centena de feridos, 2500 desalojados, afectando (danos ligeiros a colapso total) cerca de $35 \%$ do edificado no Faial e $10 \%$ no Pico.

- 12 de fevereiro de 2007. De magnitude 6,1, foi o sismo mais forrte sentido em Espanha desde 1969. Teve seu epicentro a cercad de $200 \mathrm{~km}$ do Cabo de São Vicente. Foi sentido em quase toda Península e provocou o desalojamento de pessoas. Em 12 de agosto de 2007 outro sismos de magnitude 5,1 foi registado, com epicentro na Ciudad Realfoi sentido em quase toda a Península e causou alarme entre a população, embora não tenha causado vitimas, mas sim perdas materiais como a sala de conferências do Teatro Municipal de Almagro, um edificio do século XIX.

- 17 de dezembro de 2009. O terramoto afetou toda a Andaluzia. Teve uma magnitude de 6,3 ,e provocou o pânico na população, pois temiam que ocorrecsse um tsunami. $\mathrm{O}$ sismo provocou danos em muitas casas.

- 11 de maio de 2011. O terramoto atingiu principalmente a localidade de Lorca, na região de Murcia. O epicentro localizado na Falha de Alhama de Murcia teve uma magnitude de 5,1. Foi precedido por un sismo precursor de 4,5 algumas horas antes. $\mathrm{O}$ abalo sísmico foi sentido nas províncias de Almería, Albacete, Granada, Jaén, Málaga, Alicante, Ciudad Real e algumas zonas da cidade de Madrid,A região de Murcia é a zona sismológica mais ativa de Espanha.

- 25 de janeiro de 2016. O sismo de Alhucemas, com magnitud 6,3 e epicentro no mar de Alborán, a $77 \mathrm{~km}$ noroeste da cidade de Melilla, foi sentido con maior intensidade na zona norte de Marrocos (Alhucemas, Tirhanimine e Imzouren que estão, respectivamente, a 64 e $69 \mathrm{~km}$ do epicentro) e em Melilla. Foi também sentido em Gibraltar, e em toda la costa de Almería, Granada, Málaga, Córdoba e Sevilla. No total foram registadas mais de 600 chamadas para o número de emergência 112 de Espanha. 


\subsection{TERRAMOTO E TSUNAMI DE 1755}

O sismo de 1755 é considerado como o maior dos sismos de que há notícia histórica. Sentiu-se fortemente em Lisboa, Algarve, sul de Espanha e Marrocos. Embora sem causar danos, também foi sentido por quase toda a Europa, nos Açores e na Madeira. O tsunami atingiu o norte de África, o norte da Europa, afetou os Açores e a Madeira e locais tão longínquos como Antígua, Martinica e Barbados.

Na manhã de sábado, 1 de novembro de 1755, dia de Todos os Santos, por volta das 9 h40min ocorreu um forte sismo, com epicentro no mar na zona de Gorringe. Logo após o sismo, seguiu-se um incêndio, causado principalmente pelo fogo dos fogões e das velas (Figura 17). A população fugia em direção ao rio Tejo. Entretanto, as águas do Tejo inicialmente desceram, levando consigo os barcos ancorados junto ao cais. Por volta das $11 \mathrm{~h}$ da manhã, começaram a subir de nível, galgaram as paredes do cais e avançaram pela Baixa dentro uns 300 a 400 metros (Terreiro do Paço e ruas próximas das margens). Segundo o testemunho do capitão de um navio inglês, as águas subiram cerca de 16 pés, três vezes seguidas durante 15 minutos. Só às 7 horas da manhã de domingo a maré voltou ao seu normal.

O impacto do tsunami de 1755 em Lisboa é descrito em variadíssimos testemunhos da época, como o que a seguir se transcreve (in Plano de Emergência para o Risco Sísmico de Lisboa):“(...) Eis que de repente entra o mar pela barra con huma furiosa inundação de agoas (...) Contudo passando os seus antigos limites, se lançou por cima de muitos edifícios e alagou o Bairro de S. Paulo (...)" (Mendonça, 1758), “(...) e alagou em partes com o seu fluxo e refluxo a orla das agoas que sairam do seu antigo leito e inundaram a Alfândega, o Terreiro e a Vedoria (...)". Segundo Baptista et al. (1998), a Baixa da Cidade foi inundada, sendo a distância de penetração de $250 \mathrm{~m}$, tendo a muralha "Fernandina" (refeita pelo Rei Filipe I) actuado como uma forte barreira à passagem das águas. A zona compreendida entre a antiga Ribeira das Naus, o Terreiro do Paço e o Jardim do Tabaco ficou completamente inundada.

Outra referência relata que o "Castelo do Bugio ficou tão coberto pela água que a guarnição disparou tiros de peças em sinal de socorro e foram todos obrigados a retirar para a parte mais alta da torre."

Segundo relatos da época verificou-se que os danos no edificado começaram a ocorrer na segunda fase do abalo sísmico, atingindo o máximo na terceira. Algumas pessoas tiveram tempo de fugir de suas casas entre a primeira e a segunda fase, mas muitas destas foram apanhadas pelos desmoronamentos.

O movimento das pessoas foi bastante ao acaso. Logo após o sismo, houve concentração no Largo de S. Paulo, onde às $11 \mathrm{~h} 00 \mathrm{~min}$ chegou a onda do tsunami, causando grandes perdas (Oliveira, 2005). 


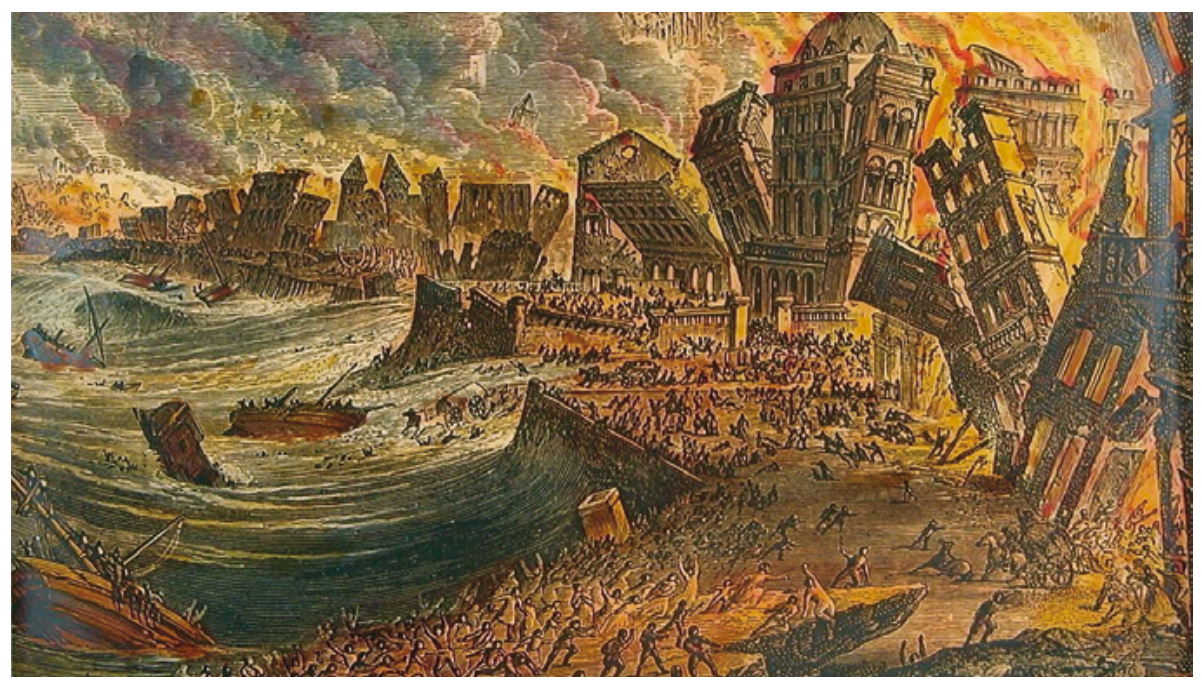

Figura 17. O sismo de 1755 em Lisboa (fonte: Getty Images).

O número total de vítimas deste sismo estima-se entre as 40000 e as 80000 pessoas. Só em Lisboa, pensa-se que dos 200000 habitantes da época, 20000 terão morrido. Das 20000 casas existentes, apenas 3000 podiam ser usadas a seguir ao sismo. Totalmente destruídos ou severamente danificados contam-se 32 igrejas, 60 capelas, 31 mosteiros, 15 conventos e 53 palácios.

Os relatos da época são pouco concordantes, tornando-se difícil conhecer o número exato de vítimas devidas ao sismo, ao tsunami e ao incêndio. Os danos provocados pelo incêndio, que durou cerca de 6 dias, foram superiores ao próprio terramoto e tsunami (Santos, 2008).

A reconstrução completa da cidade de Lisboa prolongou-se por um período de cerca de 100 anos.

No final deste capítulo os professores podem realizar as seguintes atividades:

\begin{tabular}{|l|c|}
\hline \multicolumn{2}{|c|}{ Sugestão de atividades para os alunos } \\
\hline Simula um tsunami & Página 57 \\
\hline
\end{tabular}




\section{Capítulo 6. Por que é que a minha casa treme?}

A Terra está em constante movimento e por isso pequenos sismos acontecem o tempo todo, mas não os sentimos e nem causam danos. Apenas os instrumentos de medição (sismógrafos) é que conseguem captar esses abalos mais fracos. Porém, um grande terramoto pode derrubar árvores e prédios.

Os sismos por si só não causam problema. Imagine-se um sismo no deserto: o que poderá acontecer? Nada. O que causa vítimas e danos são as construções, se não estiverem preparadas para resistir aos sismos. Não podemos prever quando a terra irá tremer, mas podemos reduzir os seus efeitos e danos se soubermos o que fazer, em casa, na escola ou na rua, antes e durante um terramoto.

Quando um terramoto ocorre, ele envia ondas através do solo em todas as direcções. Embora os edifícios sejam normalmente construídos para lidar com as forças verticais devido ao seu peso e gravidade, no entanto, não conseguem lidar com as forças horizontais transmitidas pelos sismos. Essa carga horizontal faz vibrar paredes, pisos, pilares, vigas e as ligações que os mantêm unidos (Figura 18). A diferença de movimento entre a parte inferior e a parte superior dos edificios exerce uma tensão extrema, causando a ruptura da estrutura de suporte e o colapso de toda a estrutura.

Figura 18. Comportamento de um edificio face a um sismo. Se o edificio sofrer um grande deslocamento, os elementos estruturais, incluindo vigas, pilares e paredes podem ficar danificados, tornando o edifício não utilizável (Emilio Romero Sánchez).

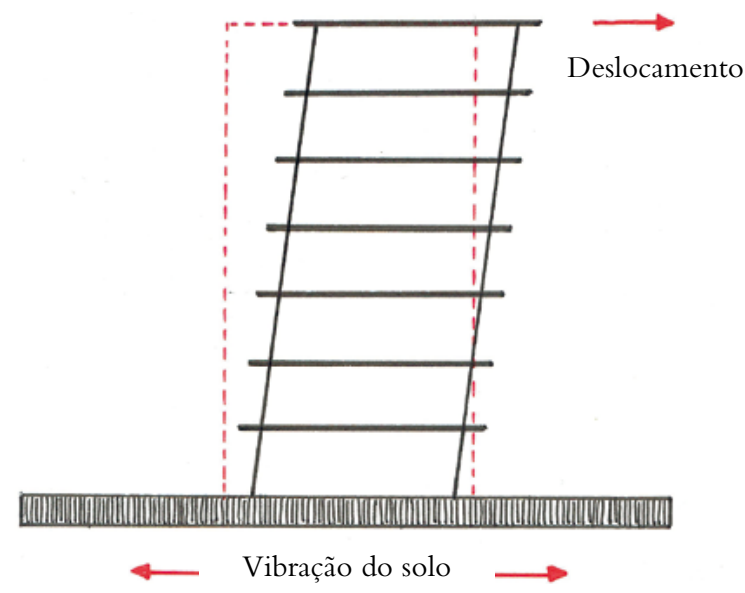




\subsection{COMO RESISTEM OS EDIFÍCIOS AOS TERRAMOTOS?}

Há vários fatores que influenciam o comportamento dos edifícios aos sismos, como sejam, a época de construção, o material de construção, o tipo de terreno de fundação, a planta (simétrica ou assimétrica), o número de pisos, entre outros.

Os edifícios podem ser construídos para resistir a sismos e serem utilizados após um abalo. Tudo depende se os regulamentos e as técnicas construtivas disponíveis são introduzidos como previsto. Importa realçar, que à medida que o conhecimento nesta área avança, as construções que antes eram consideradas seguras podem-se tornar inseguras.

Algumas soluções para que os edificios resistam aos terramotos, estão relacionadas com o reforço estrutural, diminuindo assim a vulnerabilidade.

Para se construir um edificio que resista aos sismos, os engenheiros precisam de reforçar a estrutura e neutralizar as forças de um terramoto. Como os terramotos libertam energia que empurra o edifício numa direção, a estratégia é fazer com que o prédio avance na direção oposta. Aqui estão alguns dos métodos usados para ajudar os edificios a resistir a terramotos.

O isolamento de base é uma dessas soluções: o edifício (ou estrutura) é construído sobre uma camada de isolamento (como se fosse umas borrachas, Figura 19) que isolam as fundações do solo. Quando ocorre um sismo, apenas essa camada de isolamento se move, enquanto a restante estrutura quase não se deforma, comportando-se como um corpo rígido. Edifícios com isolamento de base têm maior probabilidade de resistir a um forte terramoto e depois continuar utilizáveis.

O reforço de estruturas antigas também é uma solução. Para suportar o colapso, os edificios precisam de redistribuir as forças que os atravessam durante um evento sísmico. A existência de estruturas triangulares (Figura 20) são importantes para neutralizar a pressão e empurrar as forças de volta à fundação. 


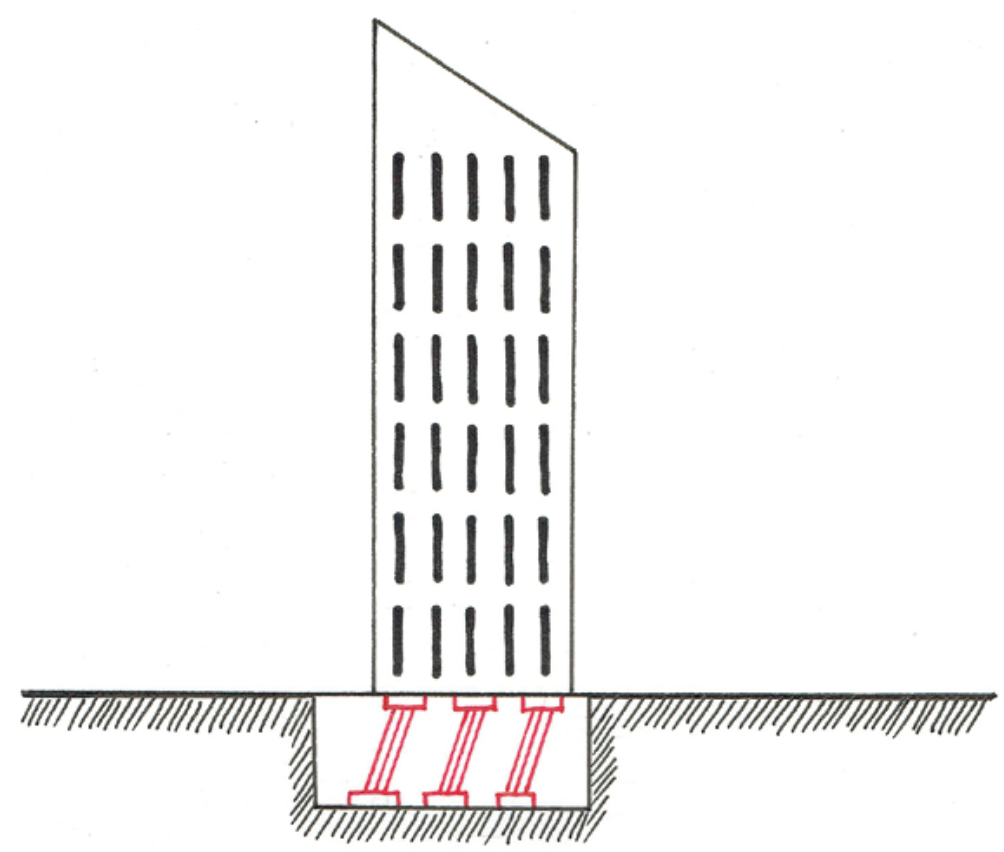

Figura 19. Isolamento de base (Emilio Romero Sánchez).
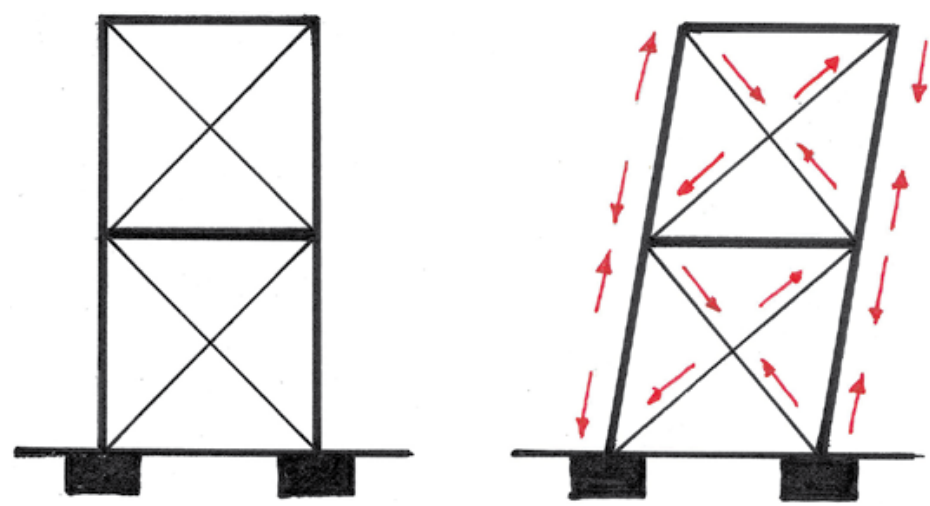

Figura 20. Adição de diagonais para contraventar a estrutura, para resistir às cargas verticais e às horizontais (Emilio Romero Sánchez).

No final deste capítulo os professores podem realizar as seguintes atividades:

\begin{tabular}{|l|c|}
\hline \multicolumn{2}{|c|}{ Sugestão de atividades para os alunos } \\
\hline A casa Treme-Treme & Página 58 \\
\hline
\end{tabular}




\subsection{IMPORTÂNCIA DOS ELEMENTOS NÃO-ESTRUTURAIS}

Num edifício os elementos estruturais são os que o mantêm de pé e que foram colocados quando foi construído: os pilares, vigas, fundações, pavimentos, escadas, estrutura da cobertura, entre outros (Tabela 1). Em caso de sismo, a qualidade da construção é importante, para garantir que o edificio não cai.

Os elementos não-estruturais num edificio não são determinantes para o manter de pé. Alguns podem fazer parte da construção, no caso do telhado e paredes divisórias, ou terem sido colocados depois, como móveis, e todo o tipo de equipamentos (Tabela 1).

Tabela 1. Elementos estruturais vs. Não-estruturais

\begin{tabular}{|c|c|}
\hline Elementos estruturais & Elementos não-estruturais \\
\hline Pilar & Telhado \\
\hline Vigas & Paredes divisorias \\
\hline Fundações & Paredes exteriores \\
\hline Pavimentos & Tetos falsos \\
\hline Escadas & Chaminé $(<6 \mathrm{~m})$ \\
\hline Estrutura da cobertura & Móveis \\
\hline Chaminé $(+6 \mathrm{~m})$ & Obras de arte \\
\hline \multirow{3}{*}{} & Equipamento \\
\hline & Computador \\
\cline { 2 - 2 } & Janelas \\
\cline { 2 - 2 } & Elevadores \\
\cline { 2 - 2 } &
\end{tabular}

Durante o movimento sísmico, os armários, as prateleiras e estantes tombam, se não estiverem bem presas, bem como os objetos que estão dentro dos armários. Os elementos suspensos, como tetos falsos, quadros, mapas, relógios e luzes caem. As portas e janelas podem sofrer deformações com o movimento das paredes, dificultando a saída e entrada de pessoas; os vidros das janelas e portas podem-se partir e os estilhaços entrarem na sala de aula ou caírem para o exterior do edificio. A eletricidade pode falhar e, consequentemente, o sistema de "sprinklers" ou de alarme de incêndios igualmente falhar. No exterior do edifício outros perigos existem, como rotura da rede de gás, queda de candeeiros, queda de edifícios, interrupção de vias por escombros, entre muitos outros (Ferreira, 2012). 
São estes os elementos que podemos fixar melhor e reforçar, evitando muitos dos perigos e acidentes de um sismo. Os estudos recentes apontam que entre 60 a 70\% dos ferimentos e internamentos, que acontecem após um sismo, são causados pela queda dos elementos não-estruturais.

\subsection{COMO REDUZIR O RISCO NÃO-ESTRUTURAL}

As medidas protetivas para reduzir os danos não-estruturais são a maior parte delas de baixo custo (ou custo zero!), de fácil aplicação e o mais importante é que os ganhos são enormes, pois podem salvar vidas, evitar ferimentos e perda de bens.

Há pequenos gestos que fazem toda a diferença. MOVER, PROTEGER e FIXAR (Figura 21) são medidas que podemos implementar para reduzir o risco dos elementos não-estruturais de cair, deslizar e causar danos, ferimentos ou obstruir as passagens, em casa, na escola ou noutro qualquer edificio.

A campanha MOVER, PROTEGER, FIXAR E REFORÇAR foi desenvolvida no âmbito do projeto KnowRISK (2017), tendo como objetivo aproximar as populações do conhecimento científico sobre a proteção contra o risco sísmico não-estrutural. Foram desenvolvidos diversos materiais para a sensibilização e comunicação do risco, sendo alguns referidos e utilizados neste guião educativo.

- MOVER os objetos pesados das prateleiras mais altas para as mais baixas. Mover/afastar uma cama que se localize por baixo de uma janela para evitar que seja atingida pelos estilhaços dos vidros.

- PROTEGER os bens mais frágeis ou valiosos. Por exemplo: o uso de fita adesiva de dupla face evita que os objetos deslizem e tombem. Colocar cortinas nas janelas, evita que os estilhaços dos vidros entrem e causem danos/cortes, sendo uma boa solução para PROTEGER.

- FIXAR às paredes os elementos não-estruturais de grandes dimensões, por exemplo estantes, armários, cacifos, roupeiros, beliches, que possam deslizar, tombar e obstruir as passagens. FIXAR bem ventoinhas, quadros, espelhos, computadores, mobiliário com rodas, equipamentos elétricos e iluminações suspensas.

- REFORÇAR os elementos não-estruturais para evitar que causem danos graves ou interrupção de funções. Por exemplo, verificar se as tubagens e condutas de gás, água e estão fixadas de forma a suportarem a acção horizontal.Verificar se as varandas ou parapeitos apresentam sinais de degradação; optar por vidros laminados ou temperados nas janelas com grandes vãos ou reforçar as chaminés são algumas das soluções (ver Guia Escola Resiliente aos Sismos e Ferreira et al., 2018). 
As soluções apresentadas na Figura 21 evitam que haja perda de bens, fator muito importante quando falamos de comércio, armazéns ou empresas. Evita igualmente que um sismo moderado cause a diminuição ou perda de função de edificios e infra-estruturas críticas como centros de operações, centros de telecomunicações, escolas ou hospitais, que devem estar a funcionar logo após um sismo (para mais informações consulte o Guia Prático KnowRISK, <https:// knowriskproject.com/>).

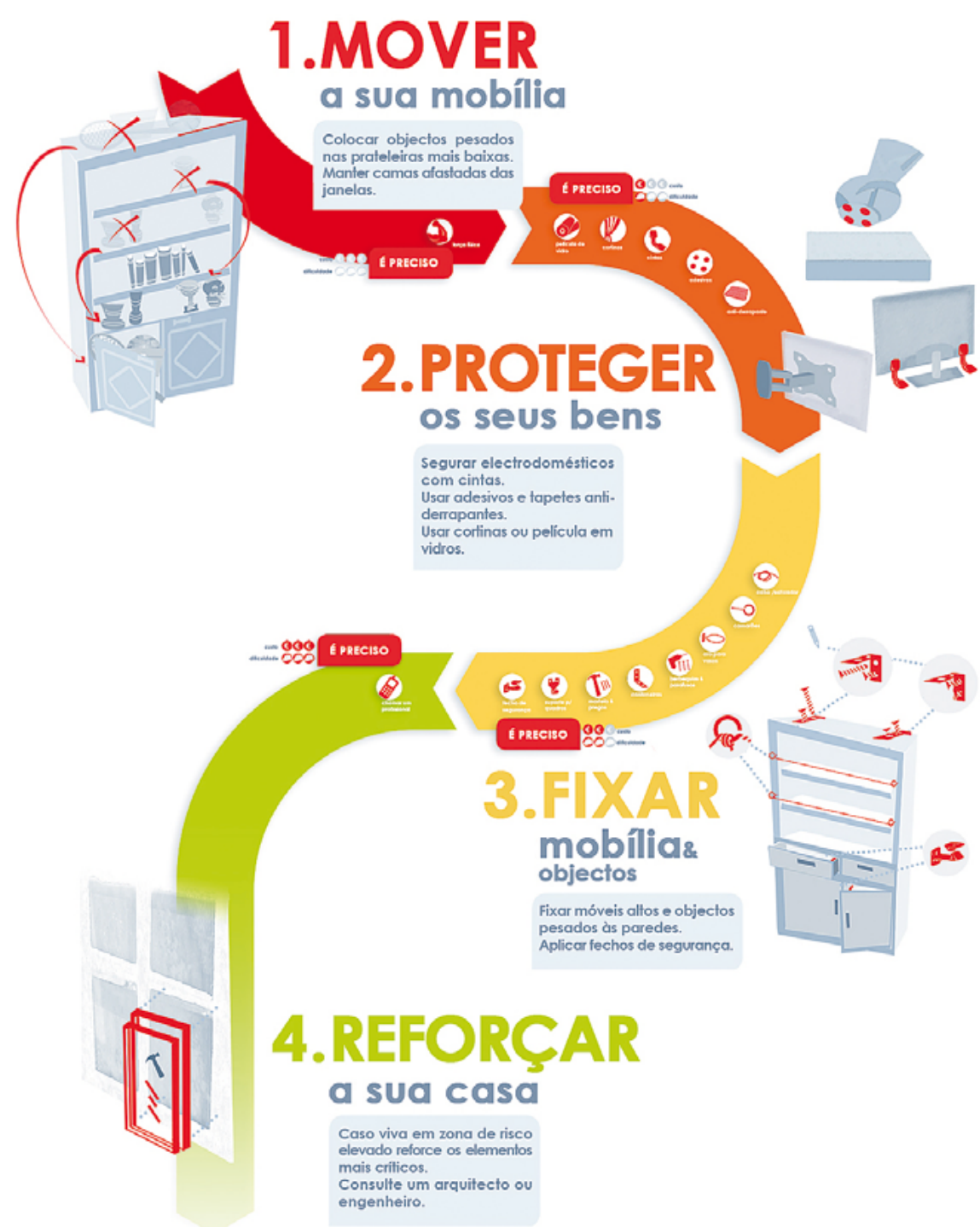

Figura 21. Medidas de proteção não-estrutural que podem ser adotadas na escola, no trabalho ou em casa: Mover, Proteger, Fixar e Reforçar (KnowRISK, 2017). 
No final deste capítulo os professores podem realizar as seguintes atividades:

\begin{tabular}{|l|l|}
\hline \multicolumn{2}{|c|}{ Sugestão de atividades para os alunos } \\
\hline Caça ao risco não-estrutural & Página 63 \\
\hline Maquete: Mover, proteger e fixar & Página 65 \\
\hline Descobre as diferenças: reduz o risco à tua volta & Página 67 \\
\hline Jogo Treme-Treme & Página 69 \\
\hline Quantos Queres: Treme-Treme & Página 70 \\
\hline Jogo de tabuleiro KnowRISK & Página 73 \\
\hline
\end{tabular}




\section{INDICE}




\section{Capítulo 7. 0 que fazer em caso de sismo e tsunami?}

\subsection{SE ESTIVER NA ESCOLA, 0 QUE DEVO FAZER DURANTE UM SISMO?}

Não abandonar a sala até terminar o abalo. Ficar longe das janelas, armários, candeeiros para nada nos cair em cima. Devemos ficar debaixo das carteiras e nunca usar as escadas nem o elevador. É fundamental manter a calma e quando o sismo terminar faz o que te ensinaram nos simulacros.

\subsection{QUAIS OS LOCAIS MAIS PERIGOSOS DENTRO DE UM EDIFÍCIO DURANTE UM SISMO?}

Junto a armários altos, roupeiros, estantes que não estão fixadas às paredes, ou cujas portas não se tranquem (portas dos armários da cozinha, por ex.). Junto às janelas, pois os vidros partem-se e podemo-nos cortar. Não estar próximo dos espelhos nem dos quadros ou de objetos que possam cair.

\subsection{SE ESTIVER NA RUA, 0 QUE DEVO FAZER DURANTE UM SISMO?}

Procurar um espaço aberto, sem árvores, prédios, postes de eletricidade ou outros elementos que possam cair sobre ti. Estar afastado dos prédios e muros das casas, pois podem cair telhas, chaminés ou elementos decorativos. Se estiveres junto à costa, há perigo de tsunami, portanto afasta-te do mar. Vai para um sítio alto!

\section{4. $O$ QUE DEVO FAZER DEPOIS DE UM SISMO?}

Terminado o terramoto, fechar o gás e a eletricidade. Sair para a rua com calma, procurar um espaço aberto afastado de edifícios e de árvores e postes de 
eletricidade e se estiveres perto do mar, vai para um sítio alto e longe da costa, por causa do risco de tsunami.

\subsection{EM CASO DE TSUNAMI, 0 QUE DEVO FAZER?}

Após um sismo e se estiver em casa, na escola, no trabalho, tenha presente que junto a zonas costeiras (de risco), tem poucos minutos para atuar (cerca de 15 min), ou seja, para iniciar os procedimentos de evacuação (Figura 22); Evacue tão depressa quanto possível, a pé, após o sismo terminar. Tenha presente que tem poucos minutos (por vezes 5-10 minutos) para chegar a um lugar alto e seguro (sem construções);

Exercite sempre os planos de evacuação (horizontal/vertical).

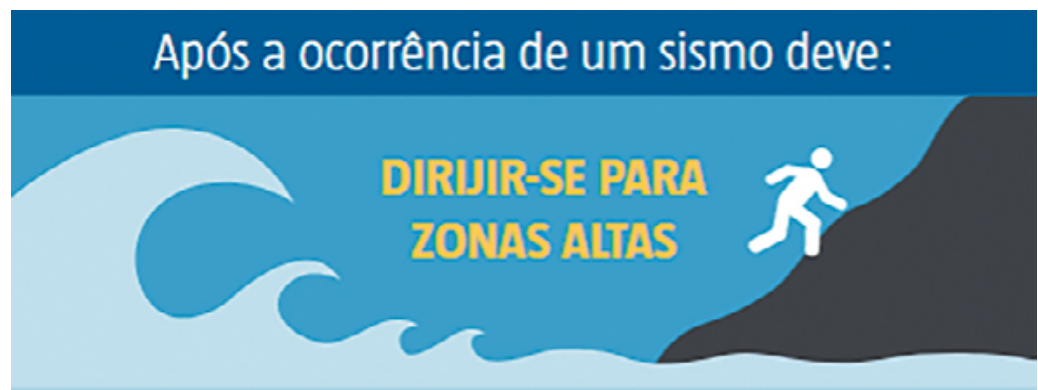

\section{O abalo sísmico é um alerta de tsunami}

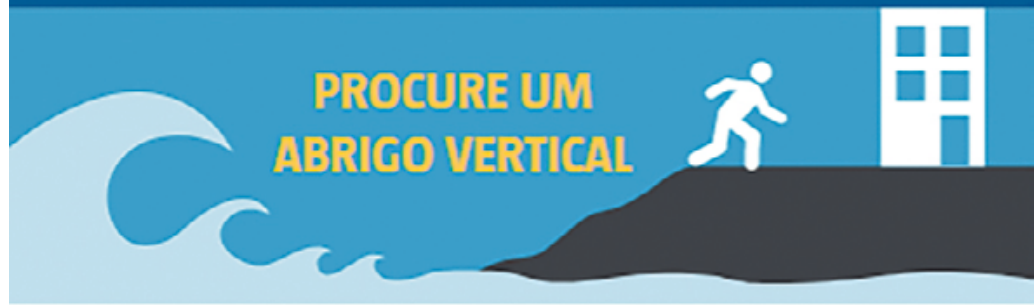

As ondas do tsunami podem durar horas

NÃO SAIA DA ZONA ALTA

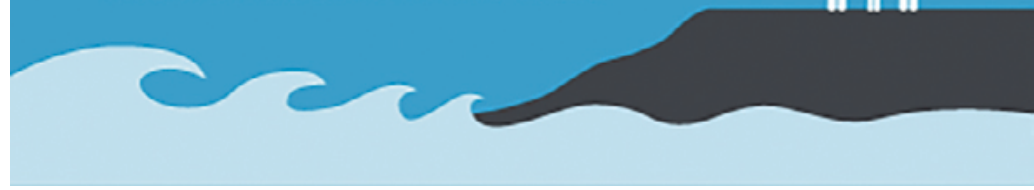

Figura 22. O que fazer em zonas costeiras após um sismo (fonte: <http://www.ceru-europa.pt>). 
Algumas praias de Portugal, nomeadamente Lagos, Portimão e Cascais já introduziram a sinalética de evacuação de tsunami (Figura 23), bem como sirenes.

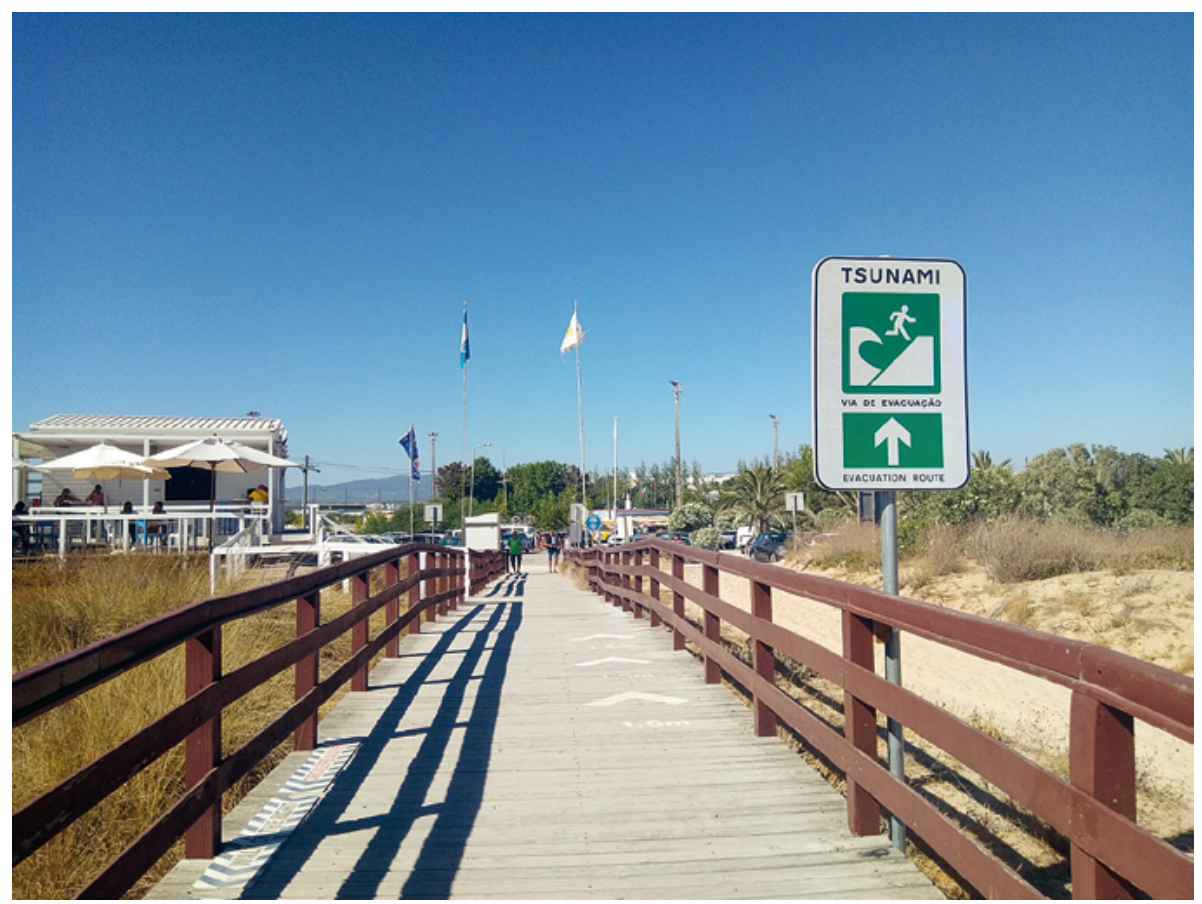

Figura 23. Risco de tsunami. Sinalética na Praia do Alvor (Foto: Mónica Amaral Ferreira).

No final deste capítulo os professores podem realizar as seguintes atividades:

\begin{tabular}{|l|c|}
\hline \multicolumn{2}{|c|}{ Sugestão de atividades para os alunos } \\
\hline Tsunamis no mundo & Página 56 \\
\hline Simula um tsunami & Página 57 \\
\hline
\end{tabular}




\section{INDICE}




\section{Capítulo 8. Atividades para alunos}

\subsection{PUZZLE PLACAS TECTÓNICAS}

Nesta atividade os alunos têm um puzzle para montar no qual constam os países, continentes e as placas tectónicas. O puzzle pode ser impresso em A4, A3, projetado ou colado sobre cartão e assim obter-se um puzzle grande que permita fazer a actividade em grupo. Este planisfério é uma excelente ferramenta de trabalho pois permite visualizar de imediato a localização das placas tectónicas em relação aos continentes e oceanos.

\section{Materiais:}

- Mapa mundo recortável.

- Blocos Lego ou de madeira.

\section{Procedimento:}

No final da atividade os alunos são capazes de:

- demonstrar como as placas tectónicas que cobrem a Terra se encaixam como peças de puzzle;

- localizar Portugal, Espanha ou outro país no seu puzzle;

- mostrar que Japão e a Califórnia estão localizados no limite da mesma placa tectónica (Placa do Pacífico), numa zona de convergência chamada Anel de Fogo do Pacífico;

- mostrar que a Austrália, por se situar no meio de uma placa e longe dos limites, não sofre terramotos; 


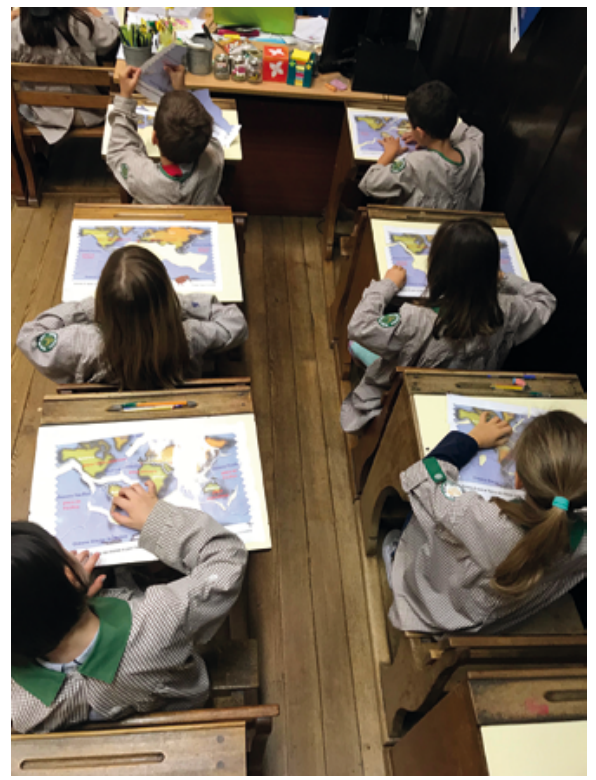

Figura 24. Alunos da primária realizando a atividade individualmente (Patrícia Gra$\operatorname{maxo})$.

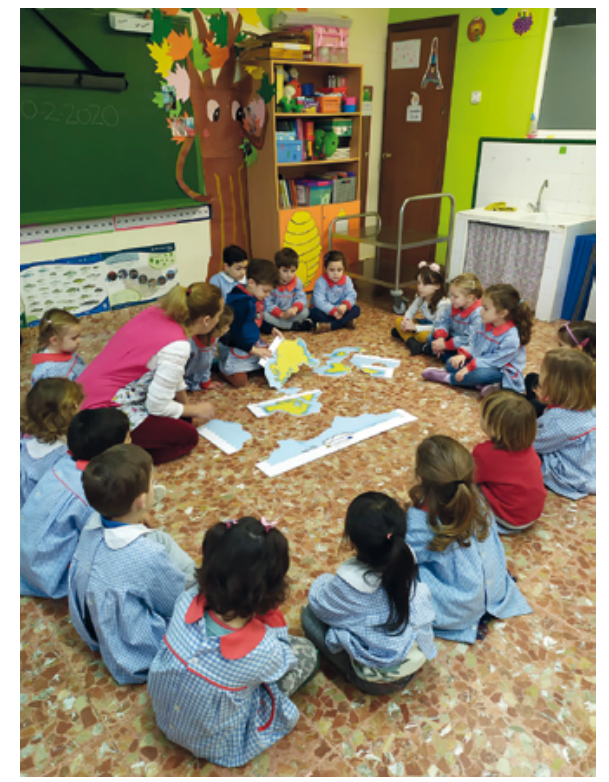

Figura 25. Atividade realizada em grupo (Beatriz Zapico Blanco).

- dar uma explicação simples da relação entre as placas tectónicas e a distribuição dos sismos no mundo, por exemplo em Portugal, na Península Ibérica;

- dar uma explicação simples sobre a formação de vulcões nos arquipélagos dos Açores, Canárias, entre outros;

- se colocarem uma pequena construção de Lego ou de madeira, em cima do puzzle, e ao baterem por baixo do tampo da mesa, os alunos compreendem que o interior da Terra faz mexer o que está à superficie dela. 


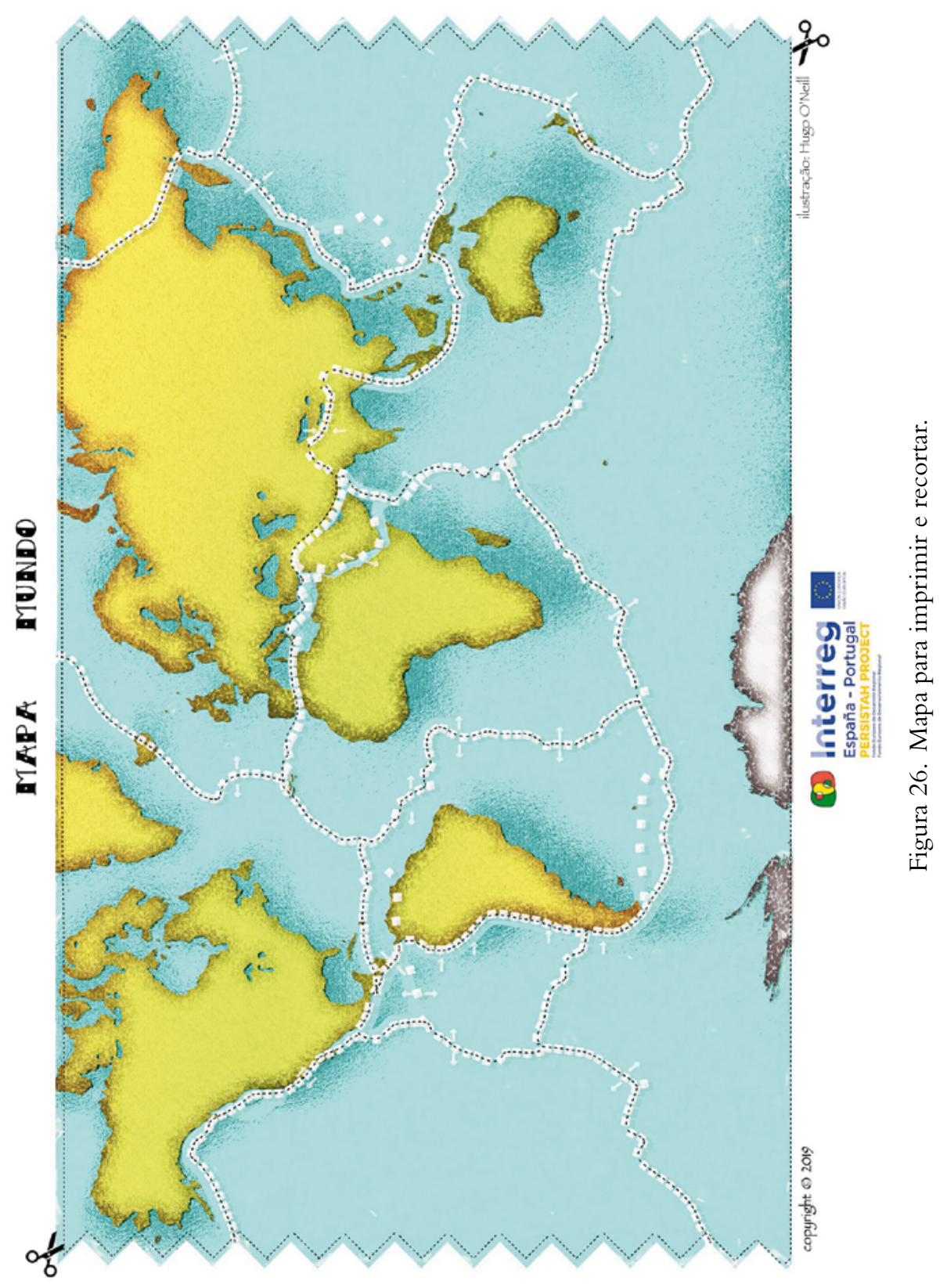




\subsection{NÃO HÁ DUAS SEM TRÊS}

Conhecer a sismicidade do nosso país é essencial para identificar os locais de maior risco. Esta atividade propõe combinar a perigosidade com a criatividade e a habilidade manual, a coordenação de cores, etc. Os alunos utilizam os mapas de Portugal e Espanha, para colorir a sismicidade (ver Cap. 5). Pode-se discutir a partir daí que outros riscos estão associados aos sismos, nomeadamente tsunamis, deslizamentos, incêndios, e o que fazer para estar mais seguro.

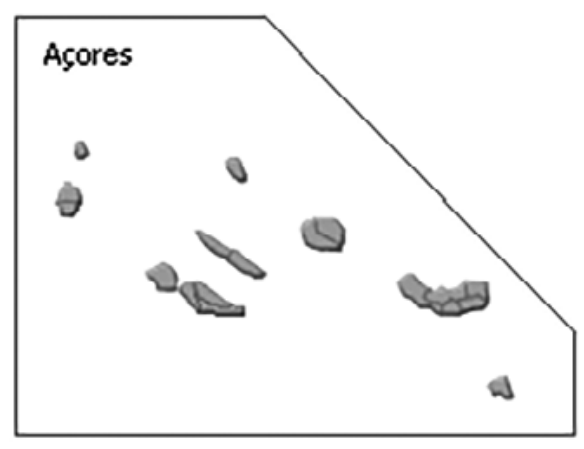

Madeira

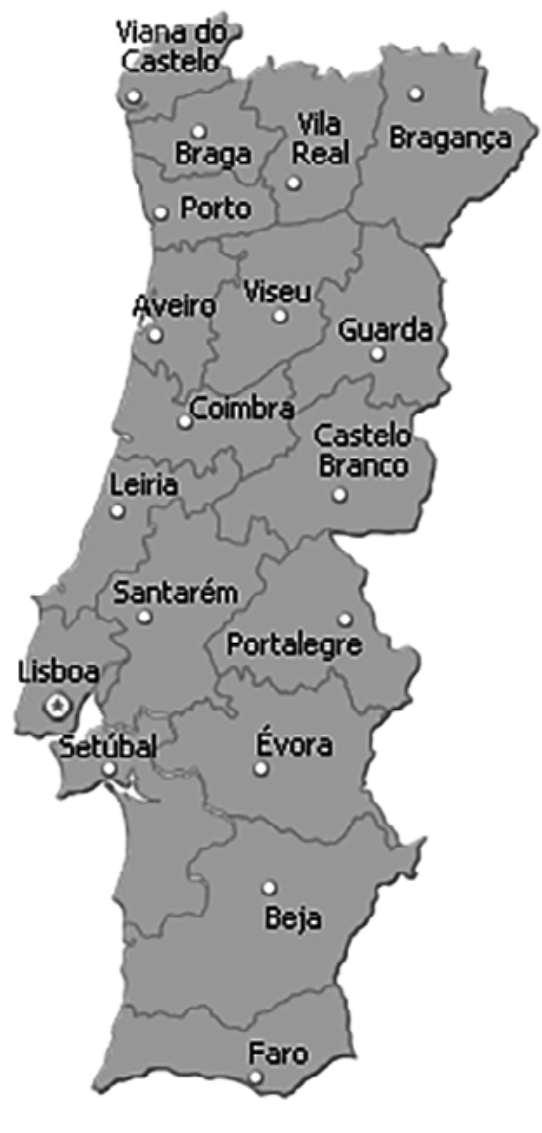

Figura 27. Mapa de Portugal. 


\section{Materiais:}

- Mapa de Portugal, Península Ibérica.

\section{Procedimento:}

- Localize no mapa a região onde vive.

- Pinte as regiões de acordo com o grau de risco sísmico: vermelho (elevado risco), laranja (moderado), amarelo (baixo) e verde (reduzido)

- Em que zona de risco sísmico e de tsunami se encontra a região onde vive?

_Elevado _ Moderado __Baixo __ Muito baixo




\subsection{LOCALIZA OS SISMOS NO MUNDO}

Por ano acontecem mais de um milhão de terramotos na Terra! Grandes e pequenos que nem os sentimos. Em Portugal, são sentidos cerca de 25 terramotos por ano. Saber exactamente onde ocorreu um terramoto é uma informação importante. Pode ajudar os sismólogos a identificar e mapear a perigosidade, assim como ajuda os cientistas a entender a localização e o movimento das placas tectónicas.
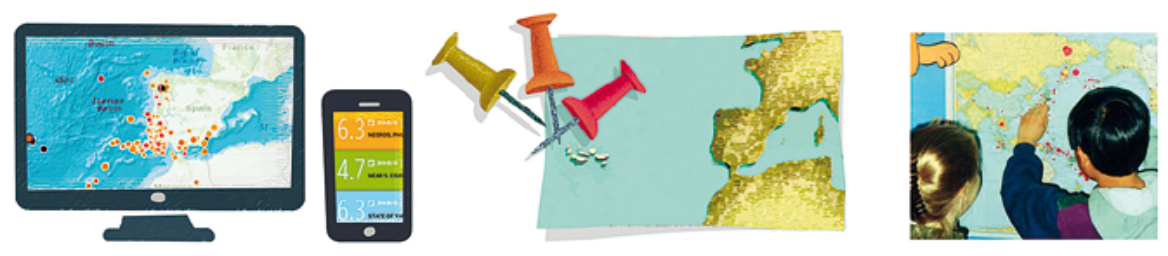

Figura 28. Figura ilustrativa da actividade (Hugo O’Neill).

\section{Materiais:}

- Mapa de Portugal, Espanha ou do mundo.

- Computador e ligação à Internet.

- Autocolantes ou pins coloridos (é importante ter pelo menos três cores, mas pode ter mais).

\section{Procedimento:}

Atribua a cada cor do autocolante/pin uma gama de magnitudes. Podemos aproveitar o acontecimento de um terramoto, em qualquer local do mundo, para levar conhecimento e pensamento crítico para a sala de aula.Visite os seguintes sites: Instituto Português do Mar e de Atmosfera (IPMA, <www.ipma.pt> $\rightarrow$ sismos $\rightarrow$ atividade sísmica); Instituto Geográfico Nacional (<https://www.ign. es/web/ign/portal $>\rightarrow$ información sísmica) ou European-Mediterranean Seismological Centre (EMSC, <https://www.emsc-csem.org>).

Pergunte onde se registaram sismos hoje no mundo e peça aos alunos que coloquem círculos vermelhos a identificar os terramotos de maior magnitude, círculos amarelos para os menores e verde para outros ainda menores. Realize esta actividade semanalmente, por exemplo, e ao longo de três meses, irão 
mapear alguns dos limites das placas tectónicas. Esta é uma boa maneira de os alunos descobrirem onde os terramotos podem ocorrer.

\section{Discussão:}

- Descubra padrões de terramotos em todo o mundo.

- Quantos terramotos ocorreram hoje?

- Localize no mapa onde se localizaram os sismos de maior magnitude.

- Por que razão os terramotos ocorrem mais em alguns locais do que em outros?

- O que têm os terramotos a ver com placas tectónicas? 


\subsection{LOCALIZA OS TSUNAMIS NO MUNDO}

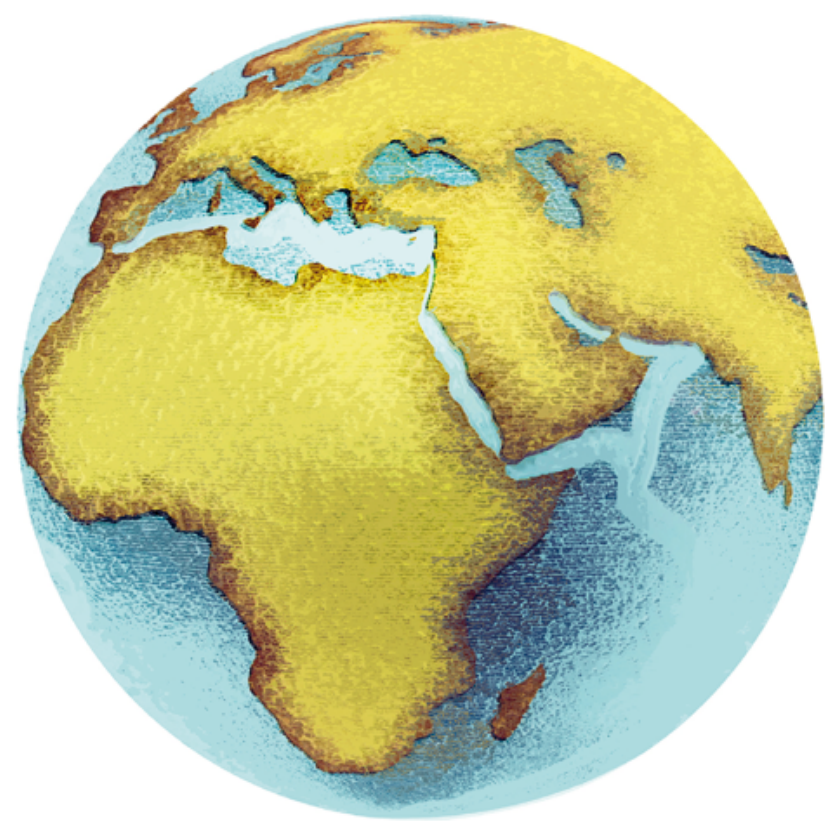

Figura 29. Globo terrestre (Hugo O’Neill).

\section{Materiais:}

- Globo terrestre ou o mapa mundo recortável.

\section{Procedimento:}

Nesta actividade, os alunos irão localizar no mapa onde ocorreram os tsunamis mais destrutivos da história e até onde chegaram:

— Tsunami de 1755 em Portugal (origem: SW do Cabo de S.Vicente).

- Tsunami de 1864 no Alasca.

- Tsunami de 2004 na Indonésia.

- Tsunami de 2011 no Japão.

\section{Discussão:}

Que relação têm os tsunamis com as placas tectónicas? 


\subsection{SIMULA UM TSUNAMI}

Nesta atividade os alunos irão simular o fenómeno do tsunami e verificar o impacto nas construções (nota: esta atividade foi criada pelo Serviço Municipal de Proteção Civil de Portimão, SMPC Portimão).

\section{Materiais:}

- Caixa de plástico;

- Argila, areia, pedras e conchas;

- Verniz e pincel;

- Miniaturas (casas, carros, árvores, peixes, etc.).

\section{Procedimento:}

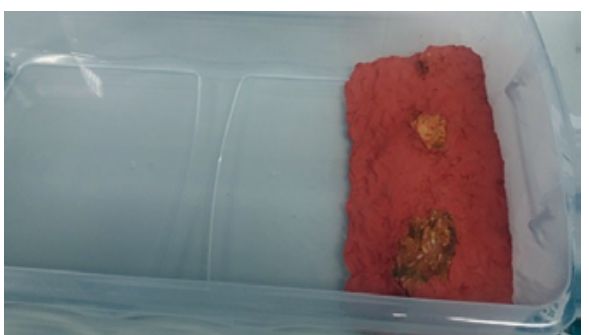

Preencha uma das extremidades da caixa com argila e algumas rochas.

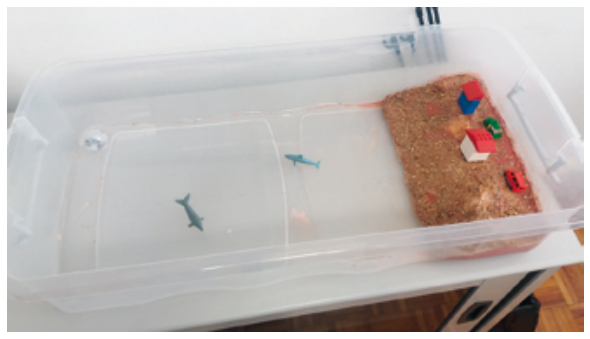

Coloque as peças na terra e na água.

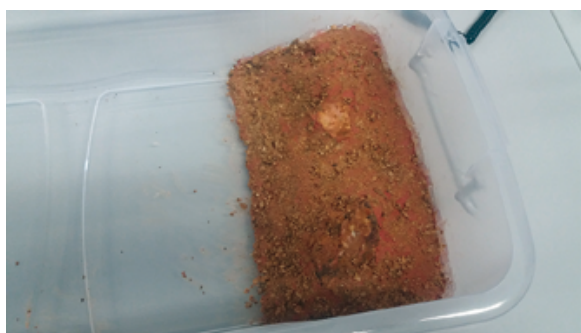

Selar com cola quente e envernizar.

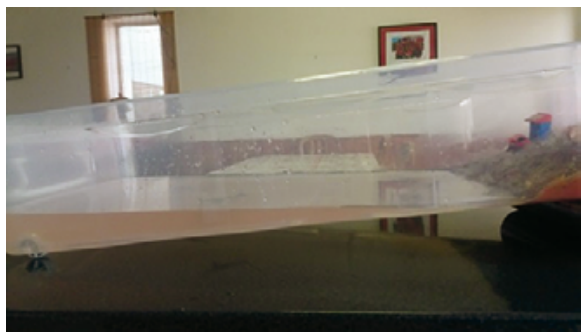

Incline um dos lados da caixa, para que a água recue. Pouse e veja o efeito do tsunami nas construções!

Fotos: SMPC Portimão. 


\subsection{A CASA TREME-TREME}

Milhares de pessoas vivem em lugares, ao redor do mundo, onde os terramotos são comuns. A maior parte da destruição causada por terramotos é resultado do colapso de estruturas como edificios, hospitais, pontes, etc. É por isso que a engenharia sísmica é tão importante. Ao projectar edificios e outras estruturas que podem suportar as vibrações, os engenheiros salvam vidas.

\section{Materiais:}

- 1 folha de papel A4;

- Espaguete;

- Marshmallows/gomas.
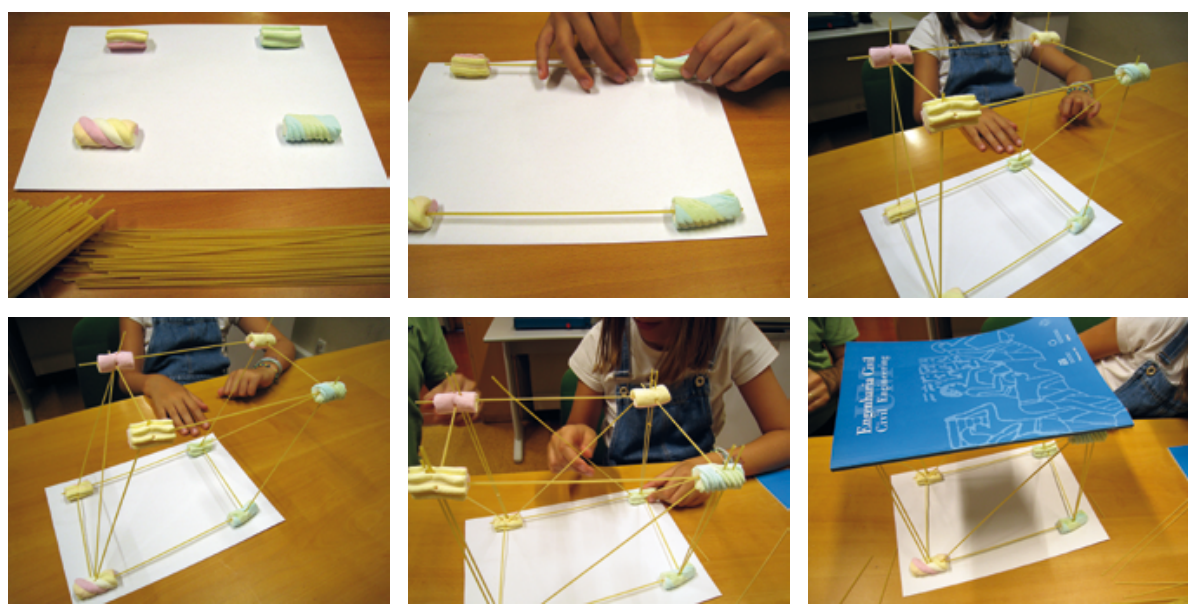

Figura 30. Estrutura de espaguete (Mónica Amaral Ferreira).

Ou:

- 1 base de cartão A4;

- 20-30 palhinhas de café (plástico ou madeira - comp. $\pm 14 \mathrm{~cm}$ );

- Plasticina. 

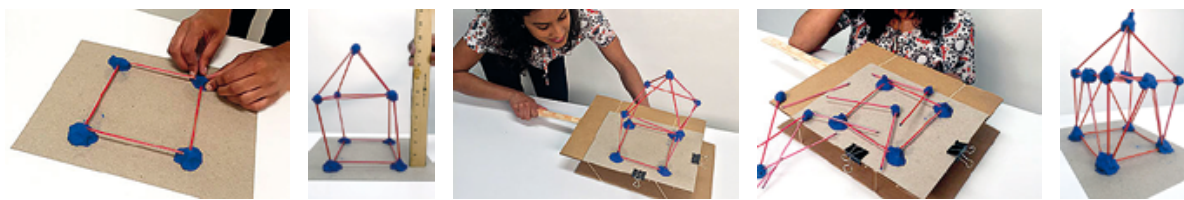

Figura 31. Estrutura de palhinhas

(<https://pbskids.org/designsquad/build/seismic-shake-up/>).

\section{Procedimento:}

Comece por fazer uma estrutura, com cerca de $20 \mathrm{~cm}$ de altura, estável e resistente o suficiente para sobreviver às vibrações de um terramoto. Teste a sua estrutura, agitando a folha de papel como se de um terramoto se tratasse.

Ov:

Recorte a casa (num papel mais grosso ou cole sobre um cartão depois de recortar) e coloque-a à prova de terramotos!

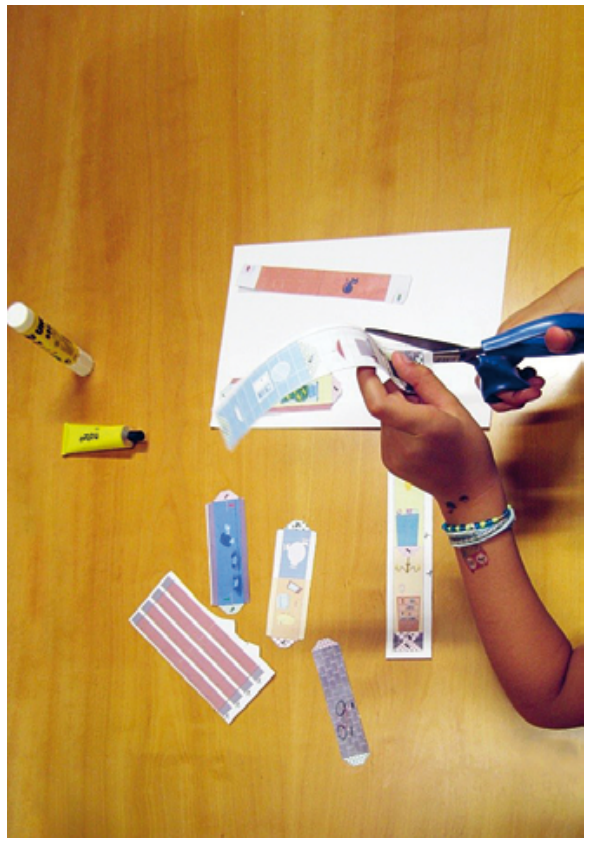

A CASA QUE

\section{TREMT}
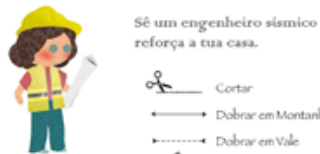

reforça a tua cass.

of $\cot t$

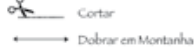

Q. Colorem
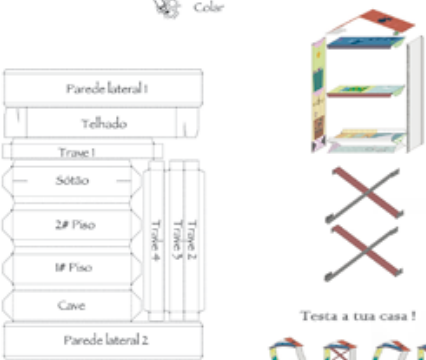

日离目要

Figura 32. A casa que treme (Foto: Mónica Amaral Ferreira). 


\section{Discussc̃o:}

Como se comportou a sua estrutura durante o abalo sísmico? Se ela oscilou, tombou ou desmoronou, é hora de fazer um novo projecto. Pretende-se que a sua estrutura seja a mais forte e estável possível.

A estrutura comportou-se bem? Siga para o próximo nível e construa uma estrutura ainda mais alta!

\section{E se...}

... a sua construção tombar? Talvez tenha uma base muito pequena; torne-a mais larga e resistente.

...a sua construção oscilar? Transforme quadrados em triângulos, adicionando diagonais para maior estabilidade

.... a sua construção colapsar? Adicione formas triangulares. Os triângulos são mais fortes que os quadrados ou rectângulos, devido á sua rigidez geométrica; o triângulo é o único polígono que não se deforma. 


\section{A CASA QUE TREME}

Sê um engenheiro sísmico e reforça a tua casa.
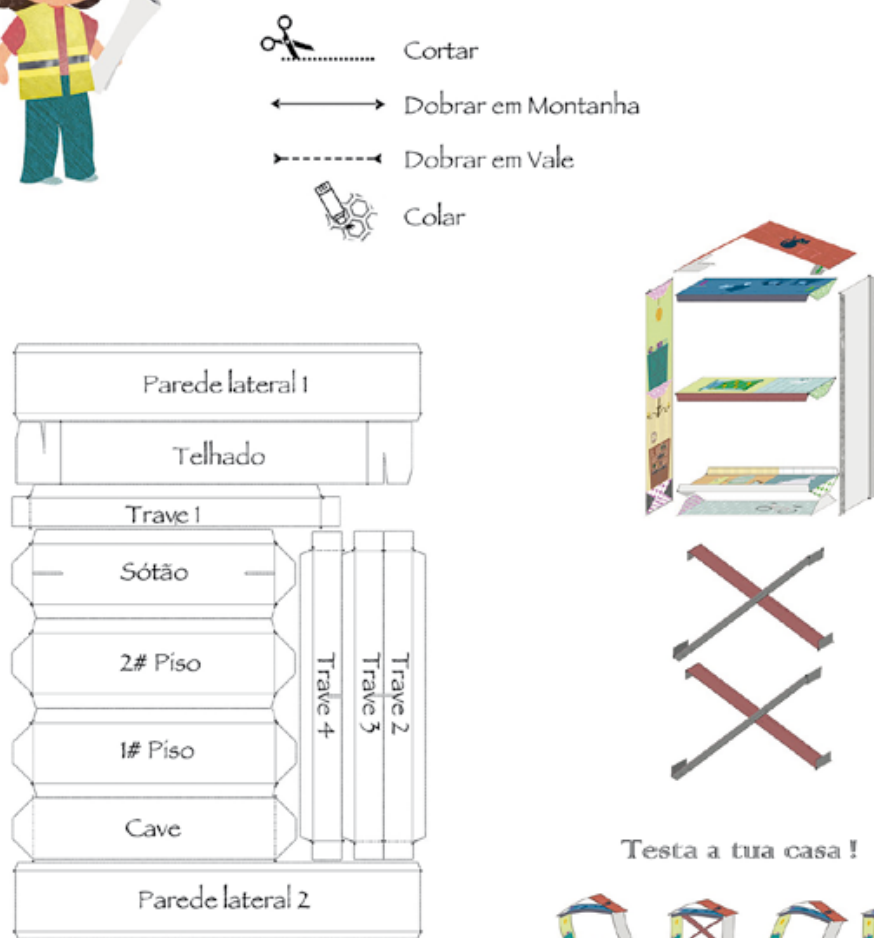

copyright (c) 2019

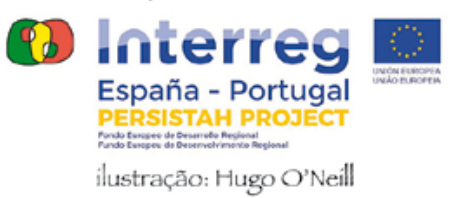




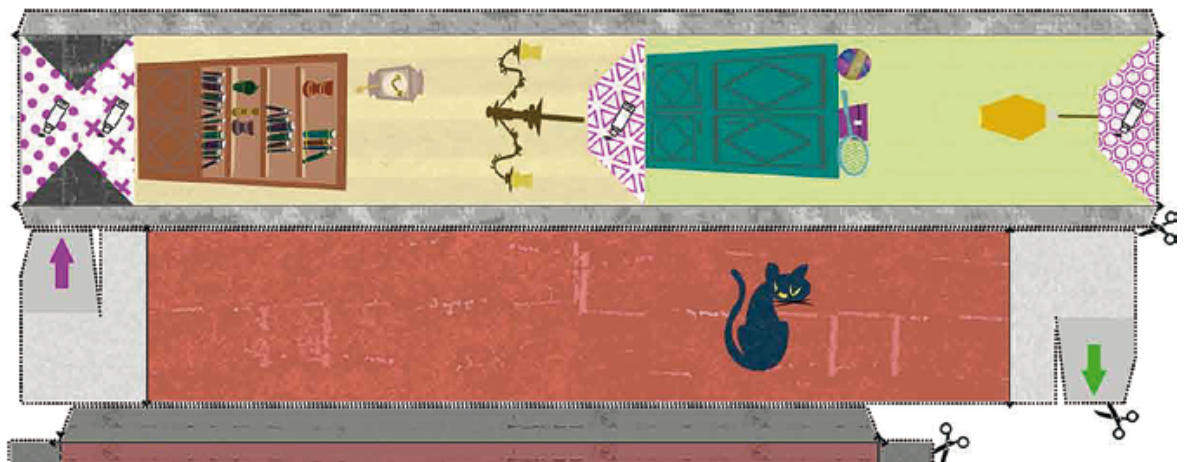




\subsection{CAÇA AO RISCO NÃO-ESTRUTURAL}

Vais preencher, com a ajuda da tua família, uma ficha de inspecção visual dos potenciais perigos existentes em tua casa (quartos, sala, escritório e cozinha), uma tarefa que costuma ser feita por engenheiros e arquitectos para avaliar a segurança das estruturas e desenvolver planos para prevenir danos em caso de sismo.

Podes fazer um filme, uma apresentação, uma entrevista ou um desenho com o que identificaste. Indica também algumas soluções que tornavam a tua casa mais segura em caso de sismo.

Podes utilizar este trabalho e apresentar as tuas observações e sugestões, ao responsável da escola, para melhorar a segurança na tua sala de aula e escola.

\section{Material:}

— Ficha de Avaliação.

\section{Discussão:}

- Pergunte aos alunos o que eles sabem sobre elementos não-estruturais e risco não estrutural.

- Identifiquem quais as zonas mais seguras em casa.

- Onde podemos aplicar medidas protetivas?

- Que soluções podem ser aplicadas para reduzir o risco não-estrutural? 


\section{FICHA DE AVALIACÃO}

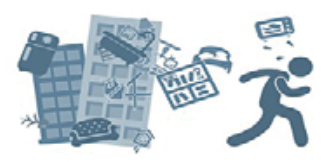

Inspector:

Data:

\section{Zona a identificar: quarto $\square$ sala $\square$ cozinha $\square$ casa de banho $\square$ escritório $\square$ outro $\square$}

\section{Identifique:}

\begin{tabular}{|l|c|c|}
\hline \multicolumn{1}{|c|}{ Tectos e cargas } & Existe? \\
\cline { 2 - 3 } & Sim & Não \\
\hline Tectos falsos & & \\
\hline Aparelhos de ar condicionado/aquecimento no tecto & & \\
\hline Objetos suspensos (candeeiros, vasos, floreiras, etc.) & & \\
\hline Estuques decorativos de tectos & & \\
\hline Tubagens/condutas & & \\
\hline Telhas da cobertura (exterior) & & \\
\hline Varandas & & \\
\hline Chaminés & & \\
\hline
\end{tabular}

\begin{tabular}{|c|c|c|c|}
\hline \multirow{2}{*}{ Mobiliário e equipamento } & \multicolumn{2}{|c|}{ Existe? } & \multirow{2}{*}{$\begin{array}{c}\text { Estão bem } \\
\text { fixados? }\end{array}$} \\
\hline & Sim & Não & \\
\hline \multicolumn{4}{|l|}{ Armários, cacifos, roupeiros } \\
\hline \multicolumn{4}{|l|}{ Armários de arquivo } \\
\hline \multicolumn{4}{|l|}{ Estantes } \\
\hline \multicolumn{4}{|l|}{ Quadros de parede, apliques } \\
\hline \multicolumn{4}{|l|}{ Elementos decorativos fixados à parede tais como estatuetas, esculturas } \\
\hline \multicolumn{4}{|l|}{ Televisão, projetores, microfones, colunas de som } \\
\hline \multicolumn{4}{|l|}{ Computadores, impressoras, fotocopiadoras } \\
\hline \multicolumn{4}{|l|}{ Extintores } \\
\hline \multicolumn{4}{|l|}{ PlayStation, XBox } \\
\hline \multicolumn{4}{|l|}{ Mobiliário/equipamentos com rodas } \\
\hline \multicolumn{4}{|l|}{ Objetos de arte, vasos com plantas em estantes altas } \\
\hline \multicolumn{4}{|l|}{ Aquários } \\
\hline \multicolumn{4}{|l|}{ Janelas, portas de vidro } \\
\hline \multicolumn{4}{|l|}{ Ventoinhas } \\
\hline \multicolumn{4}{|l|}{$\begin{array}{l}\text { Equipamento de cozinhas (fogão, forno, frigorífico, máquinas de lavar } \\
\text { roupa/louça) }\end{array}$} \\
\hline Portas dos roupeiros e dos armários da cozinha com fechos de segurança & & & \\
\hline
\end{tabular}




\subsection{MAQUETE: MOVER, PROTEGER E FIXAR}

Em conjunto, os alunos irão construir uma pequena maquete para simular o interior de um espaço (quarto, sala, cozinha, sala de aula ou outro), que posteriormente será "abanada" para mostrar como se comportam os elementos não-estruturais (objetos, elementos decorativos, vidros, mobiliário, etc.).

Primeiro colocar o mobiliário e a decoração do espaço; em seguida, identificar os riscos não-estruturais e, por fim, aplicar medidas de proteção (usando massa adesiva Bostik, mudando a disposição dos móveis, tecido para fazer de cortinados, etc.).

\section{Materiais:}

- 1 caixa de sapatos, sem a tampa;

- bocados de espuma, para a cama e almofada;

- pequenas caixas de remédios (vire-as do avesso e pinte-as) para móveis;

- pequenos espelhos redondos em tamanhos diferentes;

- peças de Lego ou mobiliário de bonecas (para fazer de móveis).
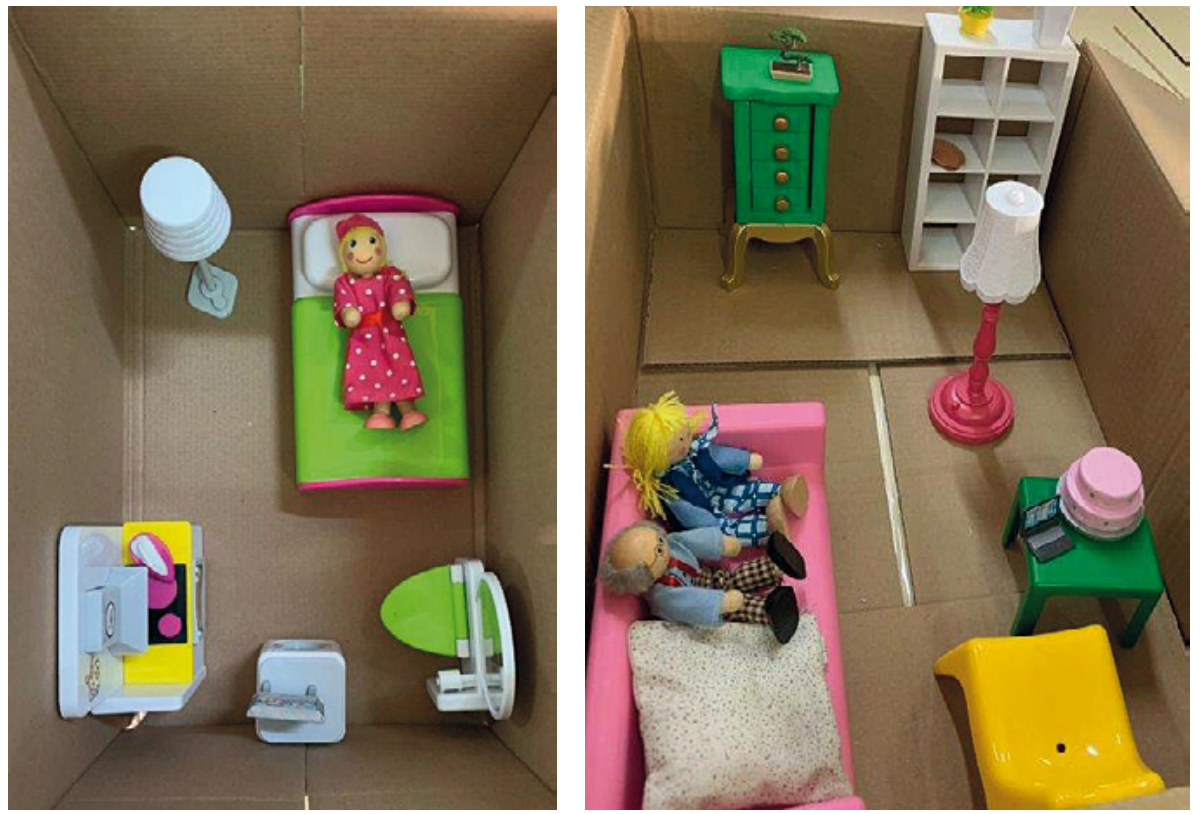

Figura 33. Exemplos de maquete com mobiliário de bonecas (Beatriz Zapico Blanco). 
A atividade pode ser realizada, em grupos, utilizando outros materiais como KLine, MDF, etc.
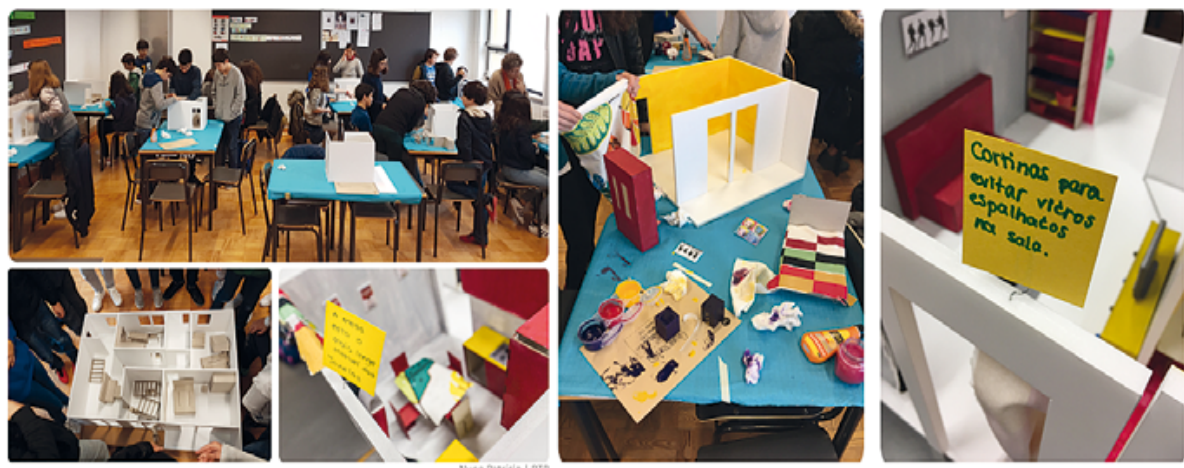

Figura 34. Fazendo a atividade com os alunos (Foto e montagem: Nuno Patrício, RTP. Marta Vicente, Delta S. Silva [KnowRISK project, 2017]).

\section{Discussão:}

- Identificar os principais riscos não-estruturais.

- Identificar as respetivas medidas de protecção.

- Discutir o tema e transpor para outros ambientes. 


\subsection{DESCOBRE AS DIFERENÇAS: REDUZ O RISCO À TUA VOLTA}

Esta é uma atividade que pode ser realizada em pequenos grupos, imprimindo a imagem ou projetando num quadro, e onde toda a turma poderá identificar as diferenças.

Normalmente a discussão intensifica-se e as crianças contam a sua própria história sobre o tema ou a situação do seu próprio quarto, por exemplo.

\section{Discussão:}

Nesta atividade, ao descobrir as diferenças nas imagens, pretende-se:

- Identificar os riscos não-estruturais na sala de aula e no quarto;

- Dar soluções para reduzir o risco;

- Envolver toda a sala de aula na discussão do tema.
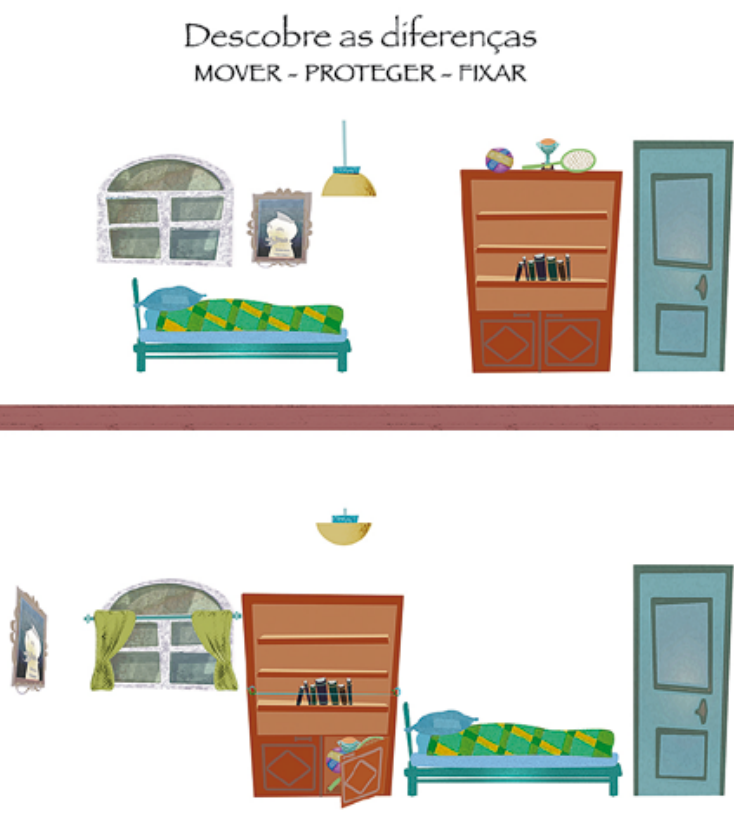

Figura 35. Descobre as diferenças (Hugo O’Neill). 


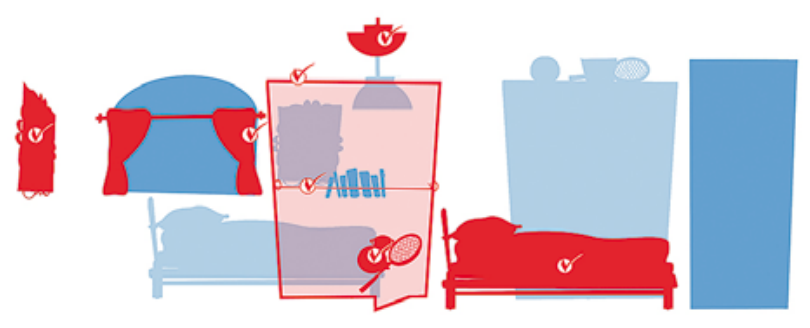

\section{PASOS PARA REDUZIR O RISCO SÍSMICO}

Reduzir os danos não estruturais e aumentar a segurança
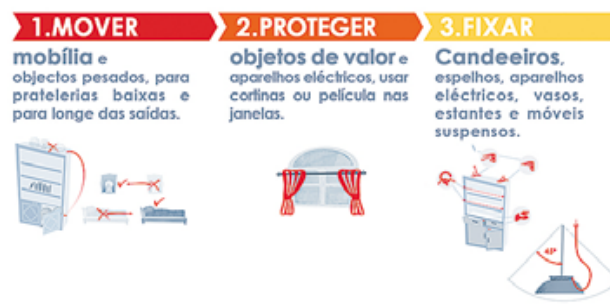

As medidas apresentadas neste guia, so por si nio senem como grantia contra perdas e danos que paskam ser cousados por futuros sismos $\mathrm{e}$ nîo sío aplicitueis em todas as situaçecs. Consulte um expecintista sempre que necessitio.

\section{KNOW Contecer a cidede iRISK através dos elementos}

Mais informaçōo ems www.knowriskproject.com

O KnowRISK ajuda a reduzir os danos não-estruturails. Para aprender mals sobre medidas de proteção de baixo custo e fácil apllcaçāo, consulta o Gula Prático KnowRISK.

copyright $\odot 2019$

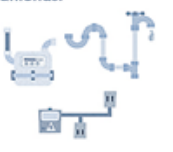

España - Portugal

Portugal =

illustration: Hugo O'Neill

Figura 36. 4 Pasos para reduzir o risco sísmico. 


\subsection{JOGO DE COMPUTADOR: TREME-TREME}

O jogo Treme-Treme permite que as crianças aprendam de uma forma divertida, conceitos apropriados para a sua idade (7-9 anos).

Este jogo educativo promove de forma lúdica a sensibilização das crianças para o tema do risco sísmico, transmite conhecimentos e estimula as novas gerações a tomarem consciência e a estarem preparadas para o problema.

O jogo, disponível em Português, Inglês, Italiano, Francês e Espanhol, é distribuído gratuitamente no site e conta com uma versão para Android na Google Play.

Visite o site <www.treme-treme.pt> e instale o jogo no computador da escola ou em casa.

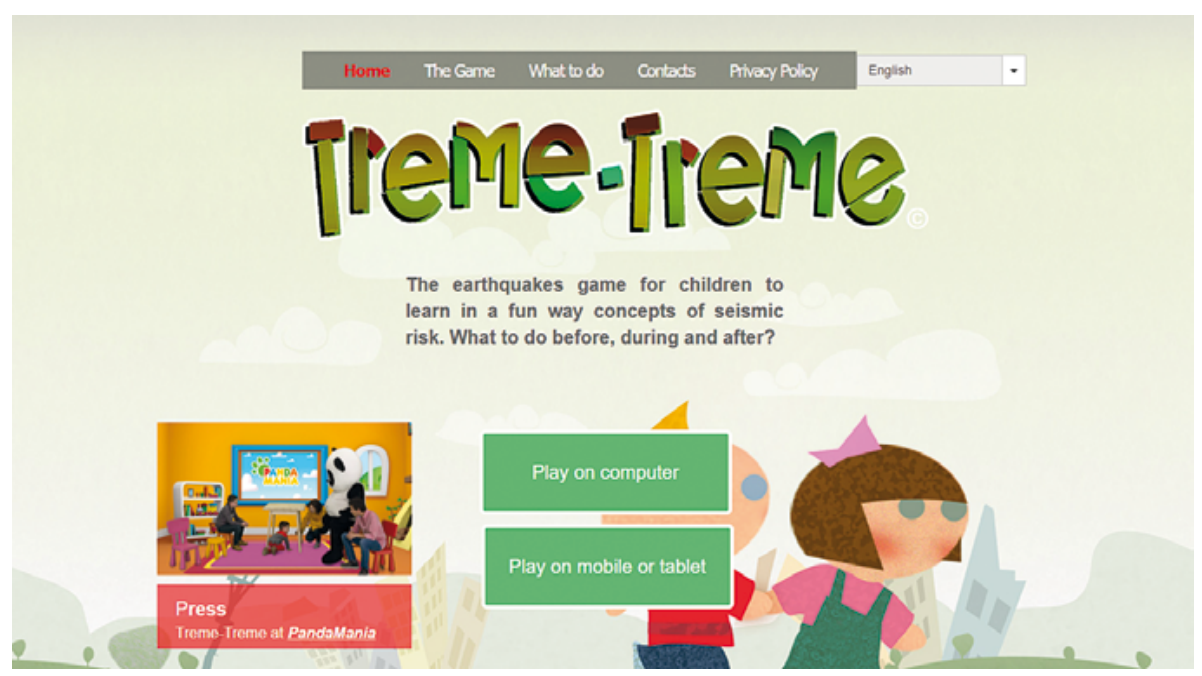

Figura 37. O jogo Treme-Treme. 


\subsection{QUANTOS QUERES: TREME-TREME}

Esta atividade está relacionada com o jogo Treme-Treme (<www.treme-treme. pt $>$ ) e tem como objetivo mostrar alguns dos objetos que devem constar de um kit de emergência. As crianças pedem um número, contam, escolhem um objeto e decidem se podem ou não levar $n$ kit de emergência. A resposta está no verso da pergunta.

\section{Materiais:}

- Quantos-Queres “Treme-Treme”;

- Tesoura.

\section{Discussão:}

- Escolher quais os objetos que constam do kit de emergência.

- Explicar porque devemos levar uns e rejeitar outros.

- Incentivar a jogar o Treme-Treme (<www.treme-treme.pt $>$ ) na escola ou em casa, pois durante o jogo cada um dos objectos é utilizado. 


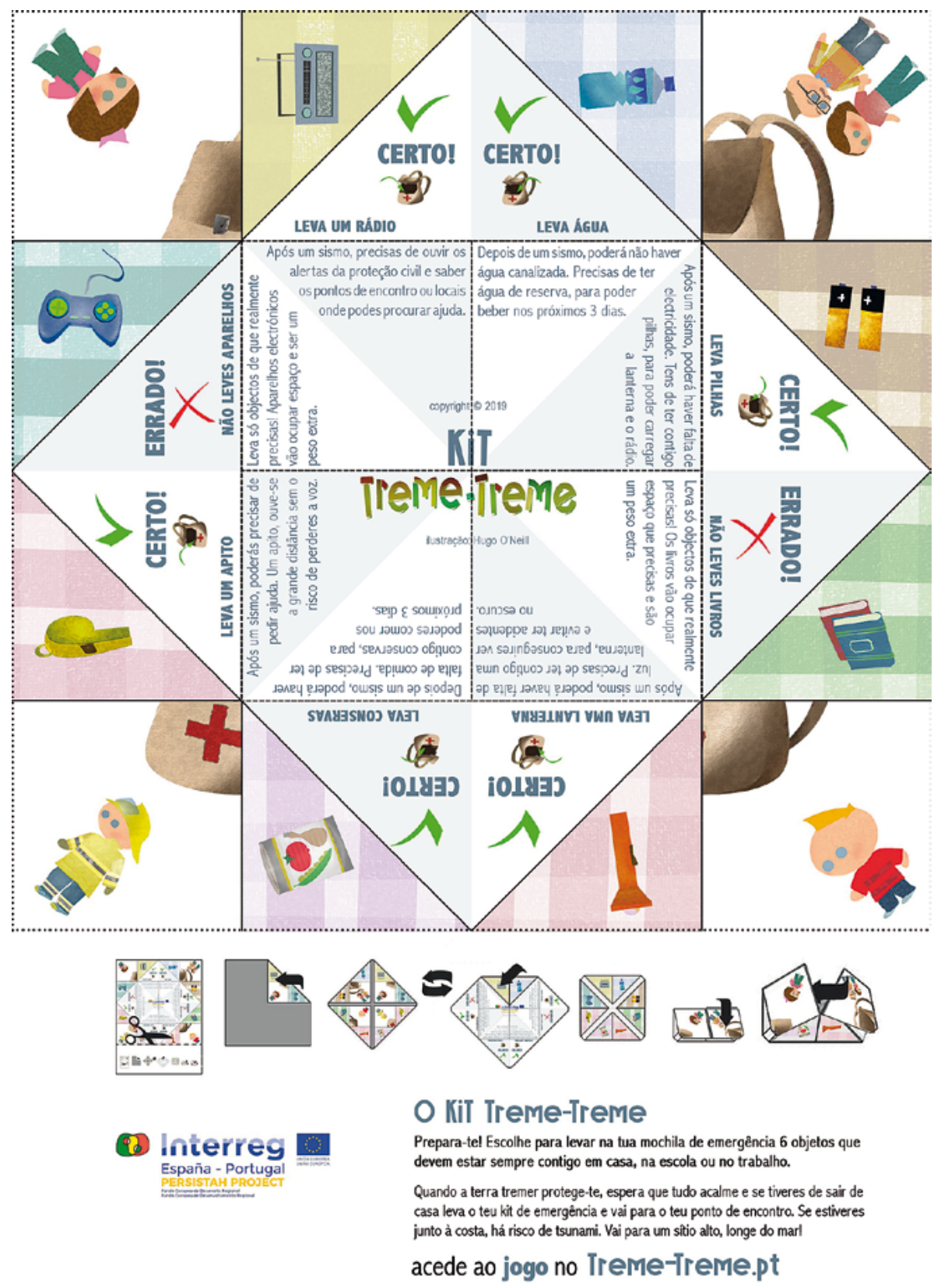




\subsection{CACA PALAVRAS}

\begin{tabular}{|c|c|c|c|c|c|c|c|c|c|c|c|c|c|c|}
\hline O & X & N & L & F & R & T & R & G & K & P & X & D & E & E \\
\hline J & L & E & I & H & O & E & L & N & K & Z & G & O & P & M \\
\hline P & F & X & H & L & T & R & G & H & K & B & M & I & N & B \\
\hline I & A & D & H & E & S & R & X & E & C & L & C & G & I & X \\
\hline R & H & N & H & L & Y & A & T & E & T & E & Y & I & B & Q \\
\hline L & N & C & V & Q & R & M & F & S & N & O & P & B & P & C \\
\hline J & I & N & X & E & J & O & I & T & U & I & R & U & L & U \\
\hline R & L & E & W & Q & O & T & R & D & I & N & Q & P & Y & A \\
\hline Q & N & C & L & I & X & O & W & T & L & S & A & S & I & G \\
\hline P & R & E & V & E & N & I & R & R & L & I & S & M & W & A \\
\hline O & W & G & S & E & D & N & C & Y & A & S & M & U & I & L \\
\hline L & M & M & N & C & F & M & K & D & C & M & I & U & W & T \\
\hline E & D & U & T & I & N & G & A & M & R & O & N & I & Y & O \\
\hline E & C & N & L & G & K & M & E & H & E & M & Y & C & A & H \\
\hline R & E & V & O & M & T & B & V & Q & M & J & P & V & N & P \\
\hline
\end{tabular}

Diverte-te procurando as seguintes palavras:

$\begin{array}{lll}\text { EPICENTRO } & \text { FIXAR } & \text { MAGNITUDE } \\ \text { MERCALLI } & \text { MOVER } & \text { PREVENIR } \\ \text { PROTEGER } & \text { RICHTER } & \text { SISMO } \\ \text { TERRAMOTO } & \text { TSUNAMI } & \end{array}$

Nota: Pode criar mais “caça palavras” em:

<http://puzzlemaker.discoveryeducation.com/WordSearchSetupForm.asp>. 


\subsection{JOGO DE TABULEIRO KNOWRISK}

Este jogo de tabuleiro é baseado no Guia Prático do projeto KnowRISK que ensina medidas simples para tornar a tua casa mais segura.

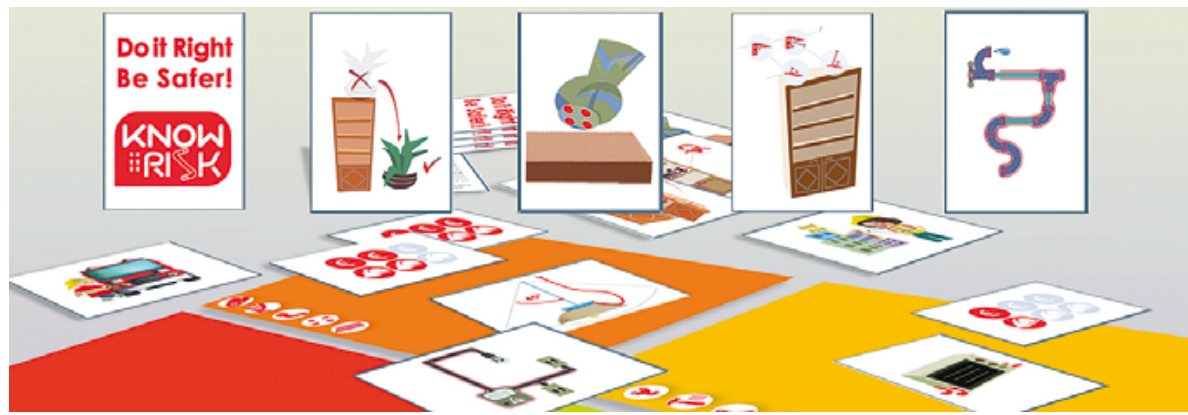

Figura 39. Jogo de tabuleiro KnowRISK.

Visite o site KnowRISK, <https://knowriskproject.com/practical-guideboard-game/?lang $=\mathrm{pt}>$, Imprima o jogo, e recorte as cartas.

Número de jogadores: 2 equipas (máximo de 4 jogadores em cada equipa) +1 moderador.

Regras: Cada equipa escolhe a uma profissão que a represente (bombeiro, agente da protecção civil, geofísico ou engenheiro).

Cada jogador tira uma carta do baralho por jogada, colocando-a num dos 4 tabuleiros (vermelho, laranja, amarelo e verde) de acordo com a acção correcta: mover, proteger, fixar ou reforçar. As equipas podem discutir entre si quais as opções certas. O moderador pode intervir, aprovando ou rejeitando as escolhas. Se a carta for rejeitada, volta para o baralho e o jogador terá de aguardar até à próxima jogada.

Vence a equipa que conseguir colocar o maior número de cartas certas no tabuleiro. 


\section{Capítulo 9. Cartaz | Segurança Sísmica nas Escolas}

Mover, Proteger e Fixar são pequenos gestos que podem salvar vidas, evitar a perda de bens e a perda de funções de um edificio.

Fixe este cartaz na sua escola! 


\section{SEGURANÇA SÍSMICA NAS ESCOLAS}

Medidas que podem fazer toda a diferença

\section{ELEMENTOS NÃO-ESTRUTURAIS}

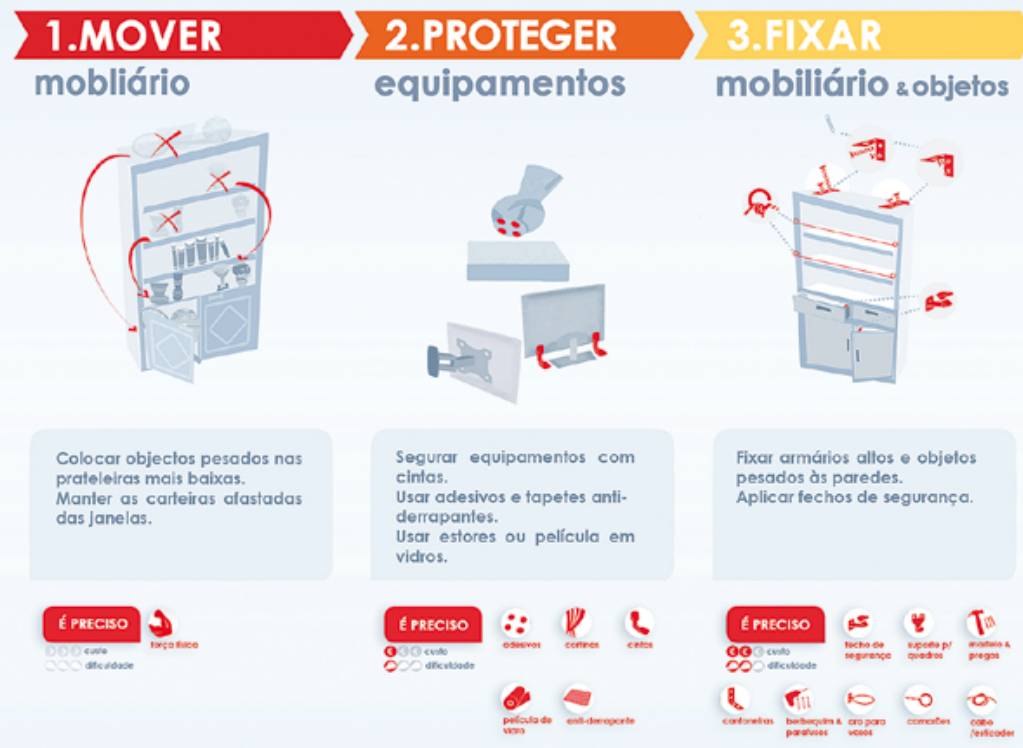

\section{EDUCAÇÃO}

\section{AUTOPROTEÇÃO}
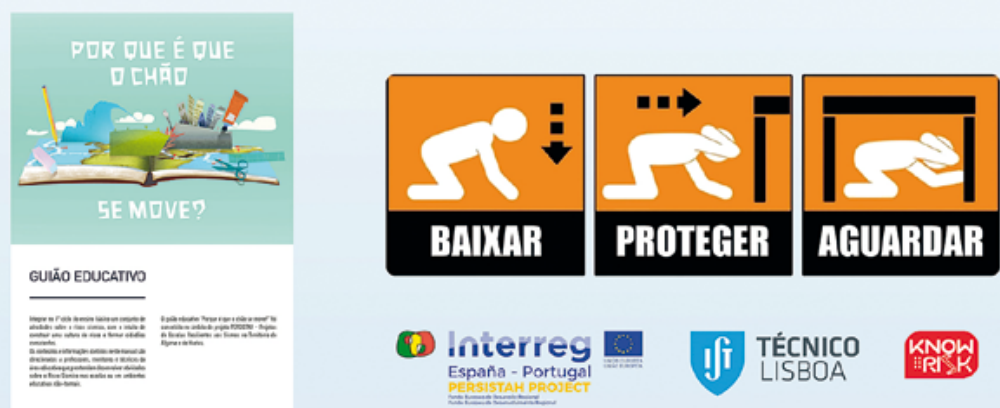

Figura 40. Segurança Sísmica nas Escolas (Hugo O’Neill). 


\section{Capítulo 10. Exemplo de protocolo experimental}

No dia 17 de junho de 2019, os 20 alunos do $1^{\circ}$ Ano B do $1^{\circ}$ CEB (6/7 anos) do Jardim-Escola João de Deus - Estrela, em Lisboa, realizaram uma atividade experimental na sala de aula. Recorrendo ao Guião Educativo "Por que é que o chão se move?", a professora do $1^{\circ} \mathrm{CEB}$ preparou o material e desenvolveu o Protocolo Experimental abaixo.

Este Guião Educativo permite que cada professor crie o seu Protocolo Experimental, ficando aqui apenas um exemplo.

EsCOLA:

LiÇÃO N ${ }^{\circ}$ :

SUMÁrIO:

\section{ATIVIDADE EXPERIMENTAL. POR QUE É QUE OS SISMOS ACONTECEM?}

\section{Introdução}

Já ouvimos notícias de sismos, terramotos ou tremores de terra que fizeram tremer o nosso planeta. Já fizemos exercícios na escola que nos ensinaram o que fazer nessas situações, por exemplo, ir para de baixo da mesa e contar até 60. A Terra está em constante movimento, e não é só por causa dos movimentos de rotação e de translação.

\section{Questão-problema}

Por que é que os sismos acontecem? 


\section{Previsões}

Assinala com uma cruz as opções que consideras que vão responder à questãoproblema. Os sismos acontecem...

\begin{tabular}{|l|l|}
\hline$\ldots$ por causa do movimento da Terra em volta do Sol & \\
\hline$\ldots$ porque a Terra tem muita água e solo abate ou mexe-se & \\
\hline ... porque a superficie da Terra é formada por placas que se mexem & \\
\hline
\end{tabular}

\section{Material}

a) Modelo do planeta Terra em plasticina.

b) Puzzle e peças de construção.

c) Barras de chocolate que representam a crosta da Terra.

\section{Procedimento}

1. Observar a estrutura interna da Terra através do modelo feito de plasticina.

2. Montar o puzzle que representa o planisfério da superfície da Terra e identificar os tracejados como placas tectónicas que compõem a crosta terrestre.

3. Fazer as duas extremidades daa barra de chocolate chocarem entre si e observar o que acontece.

4. Unir as extremidades das barras de chocolate e fazer com que elas se desloquem paralelamente em direção oposta e observar o que acontece.

5. Afastar duas metades de uma barra de chocolate e observar o que acontece.

\section{Resultados}

Quando usámos as barras de chocolate, observámos que as extremidades se modificaram, conforme os movimentos que fizemos. O mesmo acontece com os limites das placas tectónicas. 


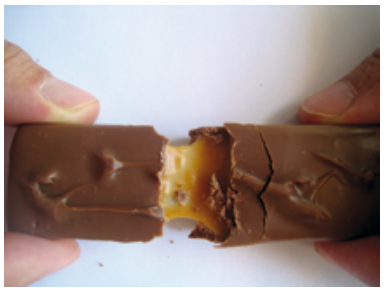

As placas divergentes

chocam entre si.

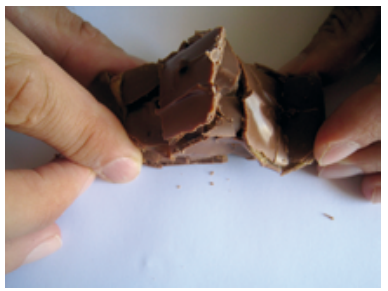

As placas convergentes

deslizam paralelamente.

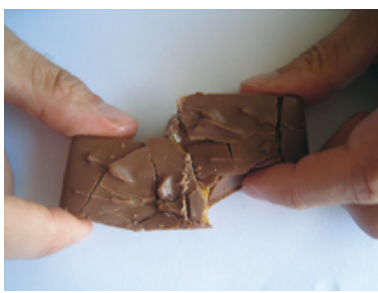

As placas transformantes

afastam-se.

Liga a través de um traço.

\section{Conclusões}

Assinala com uma cruz $(\mathrm{X})$ se as afirmações são verdadeiras (V) ou falsas (F).

a) Através desta experiência podemos concluir que:

\begin{tabular}{|l|c|c|}
\hline & $\mathrm{V}$ & $\mathrm{F}$ \\
\hline $\begin{array}{l}\text { Os sismos, tremores de terra ou terramotos acontecem porque o interior da } \\
\text { Terra é composto por materiais em constante movimento }\end{array}$ & & \\
\hline $\begin{array}{l}\text { Os sismos, tremores de terra ou terramotos acontecem porque as placas } \\
\text { tectónicas não se mexem }\end{array}$ & & \\
\hline $\begin{array}{l}\text { As placas tectónicas mexem-se porque o interior da Terra está sempre em } \\
\text { movimento }\end{array}$ & & \\
\hline
\end{tabular}

b) Com esta aula aprendemos que:

\begin{tabular}{|l|l|l|}
\hline & V & F \\
\hline Sismos, tremores de terra ou terramotos são palavras antónimas & & \\
\hline O interior da Terra é formado por núcleo, manto e crosta & & \\
\hline $\begin{array}{l}\text { A superficie da Terra parece um puzzle de placas que encaixam umas nas } \\
\text { outras }\end{array}$ & & \\
\hline A crosta é formada por várias placas ergonómicas & & \\
\hline As placas tectónicas podem chocar, afastar-se ou deslizar paralelamente & & \\
\hline $\begin{array}{l}\text { Podemos usar barras de chocolate para representar os limites das placas } \\
\text { tectónicas, por isso podemos fazer esta experiência sozinhos }\end{array}$ & & \\
\hline
\end{tabular}


c) Corrige as afirmações que assinalaste como falsas nos exercícios anteriores. 


\section{Capítulo 11. Curiosidades}

- Sabias que o terramoto também pode ser chamado de sismo, abalo de terra ou tremor de terra? São sinónimos.

- Por ano acontecem mais de um milhão de terramotos na Terra.

- Para termos uma ideia, as placas movem-se a cerca de 8 centímetros por ano. Isso é tão rápido quanto uma unha cresce num ano!

- A Placa Euro-Asiática afasta-se da Placa Norte-Americana à velocidade média de 2,5 centímetros por ano (ou 25 quilómetros num milhão de anos!).

- A maior cordilheira do mundo é submarina! A cadeia dorsal médioAtlântica é a maior cadeia de montanhas do mundo, com cerca de $15000 \mathrm{~km}$ de extensão.

- As montanhas mais altas do mundo ainda estão a crescer! Há cerca de 60 milhões de anos atrás, as montanhas do Himalaia formaram-se quando a placa Indiana colidiu com a placa da Eurásia. Hoje as duas placas ainda estão em colisão e os Himalaias continuam a subir.

- No Oceano Pacífico ocorrem mais de 80\% dos sismos na Terra, no chamado "Anel do Fogo". Esta é uma zona de elevada instabilidade geológica, cuja forma possui um aspeto de curvatura em ferradura ao longo do maior oceano do mundo. Aqui encontram-se várias placas tectónicas, tornando esta região uma zona com forte presença de terramotos e tsunamis.

- Sabias que a velocidade das ondas do tsunami pode atingir $800 \mathrm{~km} / \mathrm{h}, \mathrm{o}$ mesmo que a velocidade de avião? 


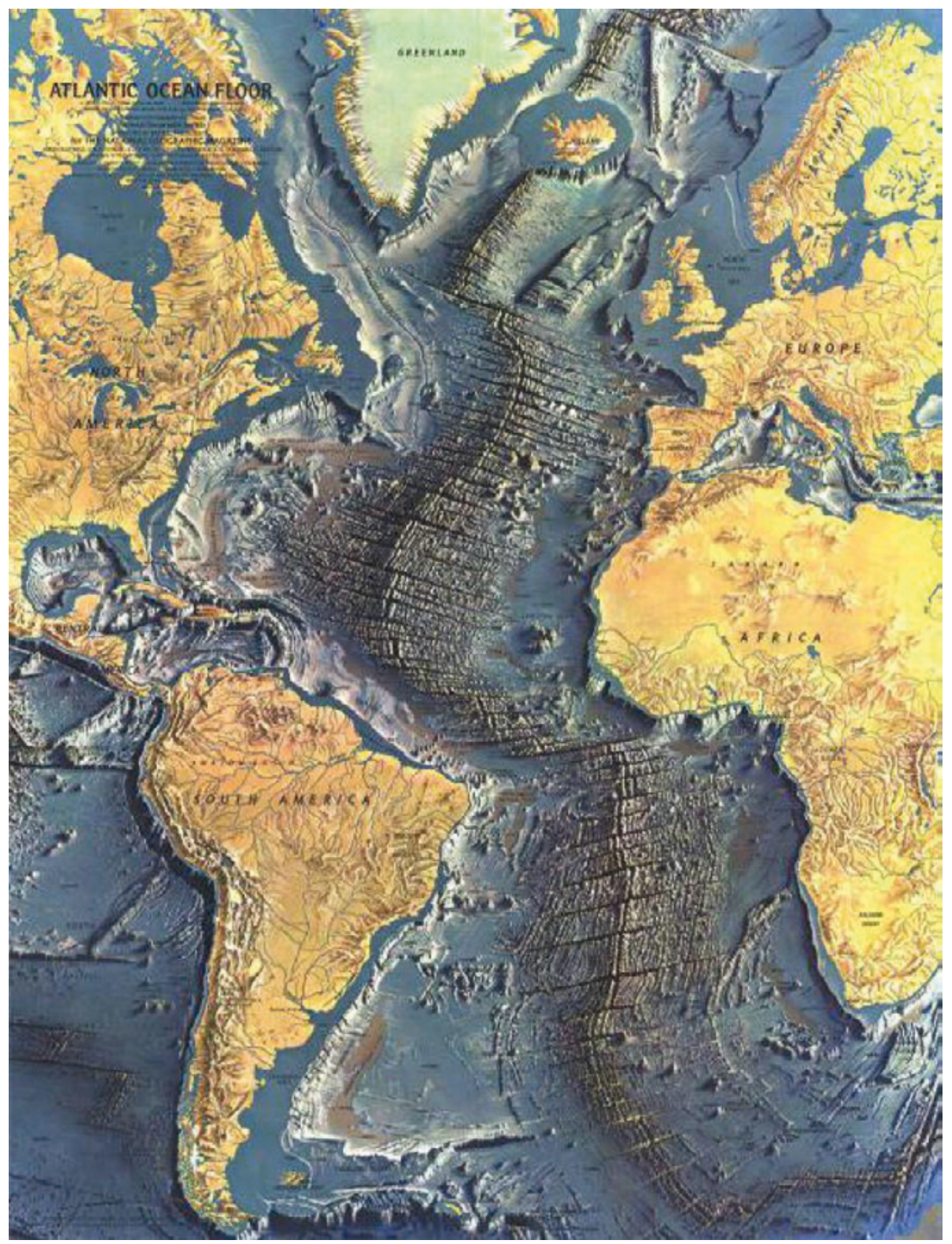

Figura 41. Cadeia dorsal médio-atlântica. 


\section{Referencias}

Chagas, I. (1993). Aprendizagem não formal/formal das ciências: Relações entre museus de ciência e escolas. Revista de Educação, 3 (1), 51-59. Lisboa.

Correia, V. (1995). Recursos didácticos. Aveiro: Companhia Nacional de Serviços, S. A.

Earthquake teaching tools for the classroom (University of California Television [UCTV]): $<$ https://www.youtube.com/watch? $=$ GQQCvsxHtjo $>$.

Ferreira, M.A. (2012). Risco sísmico em sistemas urbanos. Tese de doutoramento. Instituto Superior Técnico, Universidade de Lisboa

Ferreira, M.A., Oliveira, C.S., Mota de Sá, F., Lopes, M., Pais, I. (2018). KnowRISK Portfolio of solutions: for the reduction of seismic risk through non-structural elements. KnowRISK project (<https://knowriskproject.com/portfolio/>).

Graells, P. M. (2000). Los medios didácticos. <http://peremarques.pangea.org/medios.htm>. Inventors of Tomorrow: <https://inventorsoftomorrow.com/2017/01/30/earth_quakes-2/>. KnowRISK (2017). Know your city, Reduce seISmic risK through non-structural elements. European Commission's Humanitarian Aid and Civil Protection Grant agreement ECHO/SUB/2015/718655/PREV2. <www.knowriskproject.com>.

Magic Makers: <https://www.youtube.com/watch?v=lTMahL6xPRE $>$.

Santos, M.C. (2008). Estudo dos danos ocorridos em Lisboa causados pelo terramoto de 1755: Quantificação e discussão. Tese de Mestrado. Universidade Técnica de Lisboa Instituto Superior Técnico, Lisboa, 166 pp.

Saúde, A., Costa, E., Fernandes, J., Esteves, M., Amaral, M., Almeida, P., André, T. (2015). Referencial de educação para o Risco -Educação Pré-Escolar, Ensino Básico $\left(1^{\circ}, 2^{\circ} \mathrm{e}\right.$ $3^{\circ}$ ciclos) e Ensino Secundário. Ministério da Educação e Ciência, Lisboa.

Treme-Treme, jogo educativo, <http://treme-treme.pt/>.

Understanding earthquakes in the primary classroom: <https://www.sciencelearn.org.nz/ resources/2247-understanding-earthquakes-in-the-primary-classroom $>$.

UPStrat-MAFA (2013). Urban disaster prevention strategies using macroseismic fields and fault sources. EU Project Num. 230301/2011/613486/SUB/A5), DG ECHO Unit A5. 


\section{Índice de Figuras}

Figura 1. Organização do Referencial da Educação para o Risco (RERisco, 2015)

Figura 2. Representações do modelo da estrutura interna da Terra, usando plasticina de várias cores (Imagem da direita: $<$ http://cienciasideiaxxi.blogspot.com $>$ )

Figura 3. Estructura da Terra 15

Figura 4. Representações de como as placas tectónicas colidem (Mónica Amaral Ferreira/Hugo O'Neill)

Figura 5. Explicação "a terra treme" (Hugo O’Neill)

Figura 6. Snack de chocolate representando os movimentos e fronteiras de placas (Mónica Amaral Ferreira/Hugo O’Neill)

Figura 7. Exemplo de rifte, subducção, fossa, crosta oceânica e continental (fonte: <http://www.lneg.pt/CienciaParaTodos/ edicoes_online/diversos/guiao_tectonica_placas/texto $>$ ) .........

Figura 8. Hipocentro vs. Epicentro (Emilio Romero Sánchez) .............. 21

Figura 9. Richter e a escala logarítmica (Emilio Romero Sánchez) ........ 22

Figura 10. Energia libertada (Emilio Romero Sánchez) ......................... 22

Figura 11. Qual o efeito dos sismos nos edifícios? (Hugo O'Neill) ........... 23

Figura 12. Escala de Mercalli Modificada (Hugo O'Neill)........................ 24

Figura 13. Geracão de um tsunami (Emilio Romero Sánchez) ................ 27

Figura 14. Sinais para sabermos identificar a ocorrência de um tsunami (Hugo O’Neill)

Figura 15. Modelo geodinâmico interpretativo para a colisão das Placas Euro-Asiática e Africana (fonte: adaptado de Nunes, 1999)

Figura 16. Perigosidade sísmica em Portugal Continental

(Regulamento de segurança e acções para estruturas de edificios e pontes. 1983)

Figura 17. O sismo de 1755 em Lisboa (fonte: Getty Images) 36 
Figura 18. Comportamento de um edificio face a um sismo.

Se o edificio sofrer um grande deslocamento, os elementos estruturais, incluindo vigas, pilares e paredes podem ficar danificados, tornando o edifício não utilizável (Emilio Romero Sánchez)

Figura 19. Isolamento de base (Emilio Romero Sánchez)

Figura 20. Adição de diagonais para contraventar a estrutura, para resistir às cargas verticais e às horizontais (Emilio Romero Sánchez)... 39

Figura 21. Medidas de proteção não-estrutural que podem ser adotadas na escola, no trabalho ou em casa: Mover, Proteger, Fixar e Reforçar (KnowRISK, 2017)

Figura 22. O que fazer em zonas costeiras após um sismo (fonte: <http://www.ceru-europa.pt>) 46

Figura 23. Risco de tsunami. Sinalética na Praia do Alvor (Foto: Mónica Amaral Ferreira)

Figura 24. Alunos da primária realizando a atividade individualmente (Patrícia Gramaxo) 50

Figura 25. Atividade realizada em grupo (Beatriz Zapico Blanco). 50

Figura 26. Mapa para imprimir e recortar 51

Figura 27. Mapa de Portugal 52

Figura 28. Figura ilustrativa da actividade (Hugo O’Neill) .................. 54

Figura 29. Globo terrestre (Hugo O’Neill) .................................. 56

Figura 30. Estrutura de espaguete (Mónica Amaral Ferreira) .................. 58

Figura 31. Estrutura de palhinhas (<https://pbskids.org/designsquad/ build/seismic-shake-up/ $>$ )

Figura 32. A casa que treme (Foto: Mónica Amaral Ferreira). 59

Figura 33. Exemplos de maquete com mobiliário de bonecas (Beatriz Zapico Blanco).

Figura 34. Fazendo a atividade com os alunos (Foto e montagem:

Nuno Patrício, RTP. Marta Vicente, Delta S. Silva

[KnowRISK project, 2017])

Figura 35. Descobre as diferenças (Hugo O'Neill) ............................ 67

Figura 36. 4 Pasos para reduzir o risco sísmico................................. 68

Figura 37. O jogo Treme-Treme .............................................. 69

Figura 38. Quantos queres ................................................... 71

Figura 39. Jogo de tabuleiro KnowRISK ...................................... 73

Figura 40. Segurança Sísmica nas Escolas (Hugo O’Neill) ..................... 76

Figura 41. Cadeia dorsal médio-atlântica ...................................... 82 
Integrar no $1^{\circ}$ ciclo do ensino básico um conjunto de atividades sobre o risco sísmico, com o intuito de construir uma cultura de risco e formar cidadãos conscientes.

Os conteúdos e informações apresentados neste manual são direcionados a professores, monitores e técnicos da área educativa que prentendam desenvolver atividades sobre o Risco Sísmico nas escolas ou em ambientes educativos não-formais.

0 guião educativo "Por que é que o chão se move?" foi concebido no âmbito do projeto PERSISTAH-Projectos de Escolas Resilientes aos Sismos no Território do Algarve e de Huelva. 